Maurice A. Deane School of Law at Hofstra University Scholarly Commons at Hofstra Law

Hofstra Law Faculty Scholarship

Fall 2012

\title{
The Corporation as a Tocquevillian Association
}

Ronald J. Colombo

Maurice A. Deane School of Law at Hofstra University

Follow this and additional works at: https://scholarlycommons.law.hofstra.edu/faculty_scholarship

\section{Recommended Citation}

Ronald J. Colombo, The Corporation as a Tocquevillian Association, 85 Temp. L. Rev. 1 (2012)

Available at: https://scholarlycommons.law.hofstra.edu/faculty_scholarship/692

This Article is brought to you for free and open access by Scholarly Commons at Hofstra Law. It has been accepted for inclusion in Hofstra Law Faculty Scholarship by an authorized administrator of Scholarly Commons at Hofstra Law. For more information, please contact lawcls@hofstra.edu. 


\title{
TEMPLE LAW REVIEW
}

C TEMPLE UNIVERSITY OF THE COMMONWEALTH SYSTEM OF

HIGHER EDUCATION

VOL. 85 NO. 1

FALL 2012

\section{ARTICLES}

\section{THE CORPORATION AS A TOCQUEVILLIAN ASSOCIATION}

\author{
Ronald J. Colombo*
}

The Supreme Court's 2010 ruling in Citizens United v. Federal Election Commission re-energized the debate over the proper role of corporations in the political process. Some have welcomed the decision as an application of the Constitution's limits upon governmental regulation of political speech. Others have bemoaned the decision for equating corporate spending with free speech, thereby depriving government of the power to effectively safeguard the electoral process. Both sides of the debate, however, appear fixated upon a "one-size-fits-all" answer to the question of corporate political involvement. This is both unfortunate and inaccurate, for it undermines the construction of a positive path forward and obfuscates the truth of things.

Corporations are marked by a tremendous degree of variation and diversity, and our approach to corporate involvement in the political process ought to take this important fact into account. Many corporations live up to their characterization as simply profit-maximizing machines. To equate their "speech" with the speech of a human being would seem odd and problematic.

But some corporations belie such characterization. Some are genuine communities-a coming together of investors, business people, employees and customers around a particular vision of the good. They are marked by specific cultures, and adhere to certain principles. Such corporations provide people not merely with

\footnotetext{
- Professor, Maurice A. Deane School of Law, Hofstra University. Special thanks to Dan Greenwood, Brian McCall, John McGinnis, Susanna Ripken, and Usha Rodrigues for their generous and helpful feedback on an earlier draft of this Article, along with Suffolk University School of Law (and, in particular, Joseph Franco, Maritza Karmely, Jeffrey Lipshaw, and Anthony Polito thereof) for hosting a workshop of the Article. Finally, I am indebted to Alexandria Sawyer and Cynthia Thomas for their most able research assistance.
} 
goods, services, and jobs, but also the harmony that accompanies a life lived consistently-a life where employment and purchasing decisions are not separate from the value judgments that are constitutive of human character. These corporations should be recognized as "Tocquevillian Associations." And their participation in the political process ought to be vigorously welcomed. Indeed, their participation in the political process is arguably essential to the health of our democratic republic.

\section{TABLE OF CONTENTS}

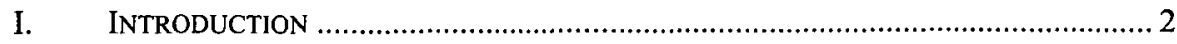

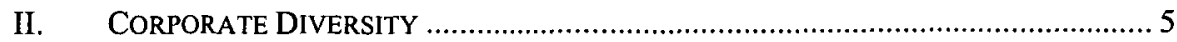

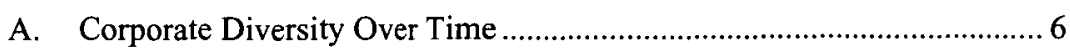

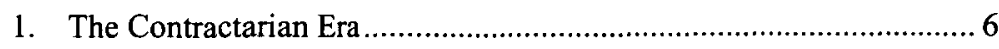

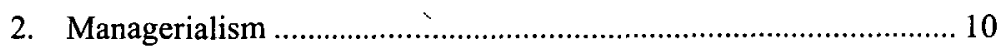

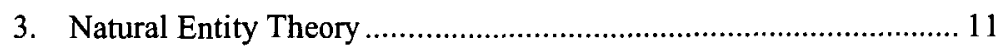

4. Aggregation Theory ................................................................... 13

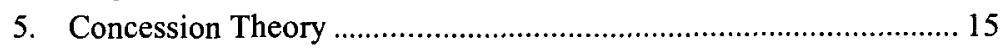

B. Modern Corporate Regulatory Diversity .......................................... 16

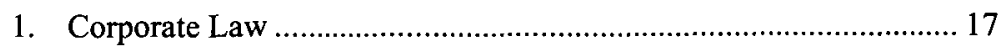

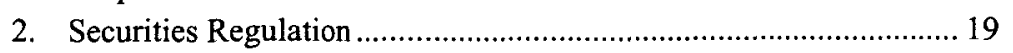

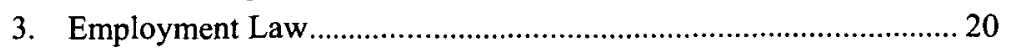

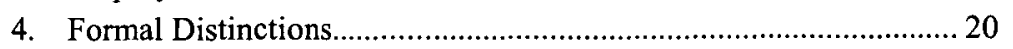

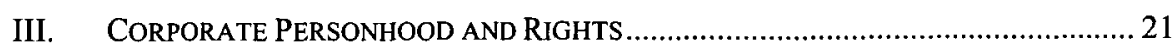

A. The Corporation as a Rights-Bearing Person....................................... 22

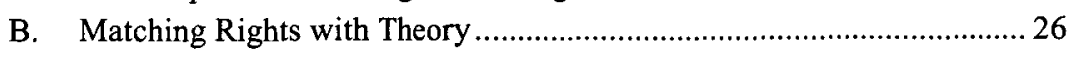

IV. THE CORPORATION AS A TOCQUEVILLIAN ASSOCIATION...................................2 29

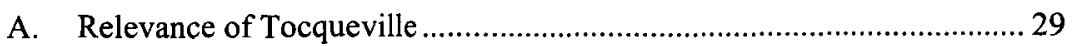

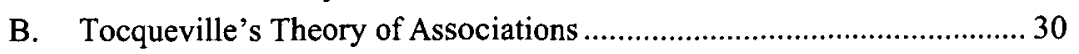

C. Characteristics of a Tocquevillian Corporate Association........................ 35

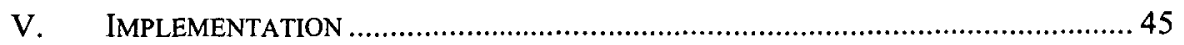

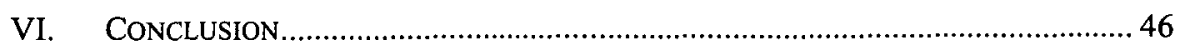

\section{INTRODUCTION}

Although the Supreme Court's 2010 decision in Citizens United v. Federal Election Commission ${ }^{1}$ has largely been characterized as a statement on corporate rights if not corporate personhood, ${ }^{2}$ the decision (and even the dissent) explicitly disavows

1. 130 S. Ct. $876(2010)$.

2. E.g., Matthew A. Melone, Citizens United and Corporate Political Speech: Did the Supreme Court Enhance Political Discourse or Invite Corruption?, 60 DEPAUL L. REV. 29, 80 (2010); Anne Tucker, Flawed Assumptions: A Corporate Law Analysis of Free Speech and Corporate Personhood in Citizens United, 61 CASE W. RES. L. REV. 497, 498 (2011). 
making any such statement. ${ }^{3}$ Instead, the decision is framed as entirely one having to do with Congressional power to regulate speech-the speaker (in this case, the corporation) being irrelevant. ${ }^{4}$

That said, the decision has raised the interesting normative question of what rights a corporation should possess. And the question is an important one for at least a couple of reasons, notwithstanding the limited grounds upon which Citizens United was explicitly decided.

First, attacks upon Citizens United continue unabated, with various efforts underway or otherwise proposed for limiting or undoing the decision. ${ }^{5}$ Some have, for example, suggested using state corporate law to reign in corporate political speech. ${ }^{6}$ Although the U.S. Constitution might preclude Congress from restricting corporate speech, ${ }^{7}$ it does not necessarily preclude state governments from amending corporate law in a way that effectively restricts the ability of entities incorporated within their jurisdiction from exercising this right. ${ }^{8}$ Thus, the issue of what rights a corporation

3. See Citizens United, $130 \mathrm{~S}$. Ct. at 900 ("The Court has thus rejected the argument that political speech of corporations or other associations should be treated differently under the First Amendment simply because such associations are not 'natural persons."'); id at 972 n. 72 (Stevens, J., concurring in part and dissenting in part) (" $[\mathrm{i}] \mathrm{t}$ is not necessary to agree on a precise theory of the corporation to agree that corporations differ from natural persons in fundamental ways"). But see Reuven S. Avi-Yonah, Citizens United and The Corporate Form, 2010 WIS. L. REV. 999, 1001 (2010) (asserting that "both the majority and the dissent in Citizens United adopt[ed] the real entity view [of the corporation]").

4. Citizens United, $130 \mathrm{~S}$. Ct. at 900 ; see also id at $972 \mathrm{n}, 72$ (noting that the theoretical conception of the corporation is also irrelevant).

5. See David. A. Westbrook, If Not a Commercial Republic? Political Economy in the United States After Citizens United, 50 U. LouISvilLe L. REv. 35, 83-84 (2011) (listing the different institutions and methods in which the case could be "rolled back").

6. Daniel J.H. Greenwood, Beyond Citizens United: The Solution, ACS BLoG (Jan. 21, 2010), http://www.acslaw.org/acsblog/node/15154. Others have introduced federal legislation to the same effect. See David Katz \& Laura McIntosh, Limitations on Contributions Would Undercut Directors, N.Y. L.J., July 28, 2011, at 5 (discussing the Shareholder Protection Act of 2011, H.R. 2517, 1 12th Cong. (1st Sess. 2011)).

7. Nonetheless, some members of Congress are attempting to effectively stymie corporate speech through indirect means. See Ambreen Ali, House Considers Citizens United Bills, CONGREsS.ORG (Mar. 11, 2010), https://ssl.congress.org/news/2010/03/11/house_considers_citizens_united_bills (discussing the efforts to promote a bill that makes company shareholders vote on any corporate spending).

8. A fascinating and important question is the extent to which a state government, through the corporate chartering process, may restrict federal constitutional rights recognized as applicable to corporations. Although the mainstream understanding is that the Fourteenth Amendment prohibits many such restrictions, see Darrell A.H. Miller, Guns, Inc.: Citizens United, McDonald, and the Future of Corporate Constitutional Rights, 86 N.Y.U. L. REv. 887, 910-11 (2011); Henri G. Minette, San Bernardino Physicians' Services Medical Group, Inc. v. County of San Bernardino: Constitutionally Protected Public Contract Property Interests Under 42 U.S.C. Section 1983, 74 MINN. L. REv. 879, 902 (1990), others are less convinced, see Matthew Lambert, Beyond Corporate Speech: Corporate Powers in a Federalist System, 37 RUTGERS L. REC. 20, 21 (2010) ("A proper analysis of the corporate form and the Constitution's applicability thereto dictates that a corporation's rights are contingent upon that which is given to it by the incorporating state, including political, press, and other protected forms of speech."). Additionally, the Montana Supreme Court attempted to distinguish Citizens United so as to uphold its own regulation of corporate campaign spending. See W. Tradition P'ship, Inc. v. Attorney Gen., 271 P.3d 1, 13 (Mont. 2011), rev'd sub nom. Am. Tradition P'ship, Inc. v. Bullock, 132 S. Ct. 2490 (2012) (striking down a Montana statute purporting to restrict political speech under Citizens United). These interesting issues are sadly beyond the scope of this Article, which shall focus on the propriety of corporate free speech rights generally, and, consequently, the propriety of efforts to facilitate versus undermine 
ought to have remains a lively and significant one.

Second, "congressional power to regulate speech" and "corporate rights" are not hermetically sealed off from one another, notwithstanding how Citizens United has been framed and generally understood. A significant amount of overlap exists. Congress's power to regulate speech (or not) only affects corporations to the extent that corporations are able "to speak." To the layperson, it may seem obvious that corporations can "speak"-indeed, corporations appear to do so all the time. Corporations run commercials, take out newspaper ads, and even have official "spokespersons." Conversely, burning a flag, or dancing topless, might not obviously constitute "speech" to the layperson-although the courts have held otherwise. ${ }^{9}$ For the term "speech," as used in the First Amendment of the U.S. Constitution is a term of art that has a particular legal meaning. ${ }^{10}$ As such, we must ultimately confront the question: are corporations capable of "speaking" as this term is understood within the context of the First Amendment? Or, more accurately in light of Citizens United (which has answered that question in the affirmative), should corporations be construed as entities capable of "speaking" as per the First Amendment?

As an answer to that question, I firmly suggest: it depends.

Corporations come in a wide variety of shapes and sizes. They differ dramatically in a number of essential details, including structure, organization, profitability, culture, and mission. ${ }^{11}$ To lump together as "corporations" all these divergent enterprises for purposes of either extending or denying free speech rights is a gross oversimplification.

In order to properly address the question of corporate speech, what is needed is a better appreciation of this diversity. ${ }^{12}$ Instead of treating all incorporated business entities as the same under the First Amendment, we ought to recognize that corporations can differ dramatically from one another, and we should expect our First Amendment jurisprudence to take this important fact into account.

This comports with the historical treatment of the corporation-which has varied

those rights. For even if the Fourteenth Amendment prohibits states from stripping free speech rights from corporations via the chartering process, there are certainly measures short of that which would have the effect of significantly thwarting the exercise of such rights. See Greenwood, supra note 6, at 104 (proposing revision of incorporation statutes to require approval of corporate political expenditures via a majority vote of "every human corporate stakeholder who is a US citizen and might be affected by the decision or expenditure, including directors, managers, employees, human investors (or the human beneficiaries of institutional investors), customers, suppliers and taxpayers who might have to pay additional taxes to replace taxes corporate taxpayers avoid or to clean up messes that such decision might allow.").

9. See United States v. Eichman, 496 U.S. 310, 318-19 (1990) (holding that burning a flag is protected speech under the First Amendment); Doran v. Salem Inn, Inc., 422 U.S. 922, 932-33 (1975) (stating that nude dancing may be entitled to First Amendment protection in some circumstances).

10. See Laurence H. Tribe, American CONSTITUTIONAl Law \$12-1, at 789 (2d ed. 1988) (discussing the competing societal consensus that make it difficult to have a straightforward definition of speech for constitutional purposes).

11. See Pamela H. Bucy, Corporate Ethos: A Standard for Imposing Corporate Criminal Liability, 75 MINN. L. REV. 1095, 1123-27 (1991).

12. But see John H. Matheson \& Brent A. Olson, A Call for a Unified Business Organization Law, 65 GEO. WASH. L. REV. 1, 33-34 (1996) (recommending a simplification of business organization law by replacing the various organizational forms available under existing law with one standard form of organization to which all new businesses must adhere) 
from era to era in light of changing facts and circumstances. It also comports with practice in our own time-which, in many situations, treats one corporation differently from the next due to relevant distinguishing characteristics.

Once we eschew a one-size-fits-all approach toward corporate free speech rights, we next must establish a means by which to appropriately distinguish those corporations that should be afforded robust First Amendment protections from those corporations that should not. For such purposes, I suggest we turn to the political theory of Alexis de Tocqueville. More specifically, I suggest we employ Tocqueville's theory of associations.

Tocqueville stressed the vital importance of associations to democratic forms of government. It is my contention that among the vast diversity of corporations, a modest number of them fit the description of an "association" as per Alexis de Tocqueville's use of that term. As such, it is not only appropriate for those corporations fitting this description to have First Amendment rights, but indeed it is absolutely essential.

This Article is organized as follows: As predicate to the argument that not all corporations ought to enjoy identical treatment under the First Amendment, Section II will demonstrate the diversity of entities that are called "corporations." It will show how, historically and in our present day, law has taken-and continues to take-into account salient factual realities in its regulation of the corporation.

Section III will discuss the interrelated phenomena of corporate personhood and corporate free speech rights. It will show how these phenomena suffer from a lack of theorization. Moreover, it will show that these phenomena have not generally tracked the historical realities of the corporate form, but rather have developed (largely) independent of such realities.

Section IV will introduce Tocqueville's theory of associations and explain how this theory can serve as an appropriate and suitable means of theorizing corporate free speech rights. Section $\mathrm{V}$ will provide a sketch of how to go about categorizing corporations (namely as free-speech-deserving versus free-speech-undeserving) in practice.

In sum, to the extent that a corporation can be characterized as a Tocquevillian corporation, it ought to enjoy the fullest protections of the First Amendment as per Citizens United. To the extent that corporations cannot be so characterized, a broad application of Citizens United to them would seem unwarranted and potentially dangerous.

\section{CORPORATE DIVERSITY}

Entities which we call "corporations" differ dramatically from one another-both historically and in our present time. This Section will set forth those dramatic differences.

Historically, as the corporation changed over time, so did its conceptualization. This changing conception of the corporation, in turn, impacted the ways in which the entity was regulated. This was both understandable and beneficial: the law did not persist in applying yesteryear's laws, based upon yesteryear's theories, to the evolving corporate entity. Instead, theory and law were adapted to conform to the factual realities of the corporate enterprise. Part II.A will set forth this history. 
And despite a general consensus over the nature of the corporation today, ${ }^{13}$ the practice of tailoring law to fit the particular corporation persists. The law does not treat all corporations similarly but rather frequently takes into account key, relevant differences when regulating corporate entities. Part II.B will set forth examples of this practice.

The variety that marks the corporate undertakings, coupled with the practice of treating different types of corporations differently, suggests that for First Amendment purposes, not all corporations should be treated similarly.

\section{A. Corporate Diversity Over Time}

In this Part, I shall review the prevailing historical conceptualizations of the corporation. I shall commence with the conceptualization that dominates our present era (the contractarian model of the corporation), and thereafter march back in time to explore those theories that came before it. This review is instructive for at least two important reasons.

First, much is to be learned from the insights of past generations regarding the corporation. Although these insights were gleaned in different times and under different circumstances, I suggest that they are far from irrelevant. To the extent that these insights go to features or characteristics that may mark certain corporate enterprises in our own time, these insights possess continued vitality and usefulness.

Second, it is good to remember that understandings and theories can and do change over time. Normatively, I add that such evolution can be a wise and good thing-especially when it is the result of changing realities and circumstances. This is a particularly important recollection as we confront the vexing question of corporate political speech. For if it seems as though the recognition of corporate political speech does not square with our prevailing understanding of the corporation, we have at least two (and not simply one) potential responses. The first (and most common) response is to reject the recognition of corporate political speech. The second is to reconsider our understanding of the corporation.

\section{The Contractarian Era}

Most scholars who think and write about corporate law today conceive of the corporation as a "nexus of contracts." 14 Grounded in the principles of economics, this conceptualization envisions the firm "not as an entity, but as an aggregate of various inputs acting together to produce goods or services." 15 These inputs are bound together by a network of "explicit and implicit contracts," which serve to structure and define

13. See infra Part II.A.1 for a discussion on the "nexus-of-contacts" conception of corporations.

14. See Stephen M. BAinbridge, Corporation LAW AND ECONOMICS $\S 1.5$, at 27, 33 (2002). Important early works advancing the nexus-of-contracts approach include Armen A. Alchian \& Harold Demsetz, Production, Information Costs, and Economic Organization, 62 AM. ECON. ReV. 777 (1972), Eugene F. Fama, Agency Problems and the Theory of the Firm, 88 J. POL. ECON. 288 (1980), and Michael C. Jensen \& William H. Meckling, Theory of the Firm: Managerial Behaviors, Agency Costs, and Ownership Structure, 3 J. FIN. ECON. 305 (1976). These in turn built upon the work of Ronald Coase in The Nature of the Firm, 4 ECONOMICA 386 (1937) and The Problem of Social Cost, 3 J.L. \& ECON. 1 (1960).

15. BAINBRIDGE, supra note 14 , at 27. 
roles, responsibilities, and relationships within the firm. ${ }^{16}$ To contractarians, the primary purpose of corporate law is to provide a set of efficiency-maximizing, off-theshelf default rules to govern the firm. ${ }^{17}$

The original impetus for the contractarian approach was, largely, a desire to more accurately capture the relationship between corporate shareholders and management. ${ }^{18}$ This was itself fueled by a growing mistrust of managers and disenchantment with the "managerialist" understanding of the firm, ${ }^{19}$ which had long been controversial. ${ }^{20}$ As P.M. Vasudev explains, the approach helped address these and other dominant concerns that had been growing since the 1960s:

- decisive managerial power in American corporations, coupled with shareholder passivism;

- $\quad$ growth strategies pursued by managers that delivered little value to shareholders;

- $\quad$ stagnant share prices and the inability of investors to derive capital gains from their shareholding;

- emerging hostility to economic regulation and an emphasis on market freedom; and

- the rise of the law and economics movement and the sidelining of non-economic considerations in policymaking. ${ }^{21}$

The contractarian approach was made possible by the work of Armen A. Alchian \& Harold Demsetz and Michael C. Jensen \& William H. Meckling who published (in 1972 and 1976, respectively) articles applying microeconomic thinking to intrafirm activity. 22 (Heretofore, microeconomists had shied away from examining intrafirm activity within the "black box" of the corporation, allowing managerialism to reign supreme without serious competition for decades. ${ }^{23}$ )

The microeconomic examination of the firm revealed that intrafirm interactions could be characterized as not even differing "in the slightest degree, from ordinary market contracting between any two people." 24 As such, each actor within the firm can

16. $I d$.

17. Id. at 29-31.

18. See William W. Bratton, Jr., The "Nexus of Contracts" Corporation: A Critical Appraisal, 74 CORNELL L. REV. 407, 410 (1989) ("'C]ontractual pictures better account for many aspects of relationships between corporate managers and security holders than do competing managerialist pictures."); Fama, supra note 15 , at 288-89 (stating that the relationship between security owners and management can be explained within the "set of contracts" perspective).

19. See infra Part II.B.1 for discussion of the managerialist view of the corporation.

20. See Bratton, supra note 18, at 413-15 (describing the debate between "anti-managerialists" and "promanagerialists").

21. P.M. Vasudev, Law, Economics, and Beyond: A Case for Retheorizing the Business Corporation, 55 MCGiLl L.J. 911,919 (2010).

22. See Bratton, supra note 18 , at 415 (describing the history of contractarian view of the corporation that challenged traditional notions of management).

23. See id. (describing how the papers published by these economists marked the advent of a new economic theory challenging traditional notions of management interaction).

24. Id. (quoting Alchian \& Demsetz, supra note 14, at 777). 
be expected to rationally pursue the maximization of his or her self-interest. ${ }^{25}$ Relationships within the firm, including rights and responsibilities, could all be interpreted in that light, thereby providing a means by which to formulate default rules of corporate law. ${ }^{26}$ The emphasis on market contracting implies voluntarism, which undermines the managerialist view of a coercive corporate hierarchy. ${ }^{27}$

The contractarian theory of the firm can also be said to represent the product of "unmitigated liberal individualism"-a philosophy that arguably has dominated political and academic discourse since World War II. ${ }^{28}$ This philosophical pedigree contributed to its success-by conceiving the firm as a contentless "nexus," contractarians maximize individual autonomy and undercut arguments supportive of state regulation. ${ }^{29}$ This approach found a particularly welcome audience in the closing decades of the twentieth century, given the deregulatory spirit of America in the 1980s and $1990 \mathrm{~s} .{ }^{30}$ It also benefitted from the ascendency of the general law and economics movement, of which it was a part. ${ }^{31}$

Another reason for the theory's success is its comportment with reality. As William Bratton has explained, for all its faults and limitations, the contractarian theory of the firm does indeed offer a "theoretical exploration" of certain "discrete aspects of practical corporate relations." 32 It helps account for the fact that different investors have different expectations, and "begins to explain the strains of corporate doctrine that persistently refuse to apply the fiduciary principle." ${ }^{33}$

Importantly, the contractarian account is consistent with the enabling nature of modern corporate statutes, and especially the ability of corporate actors to (usually) deviate from these as they see fit. ${ }^{34}$ When coupled with the ability to incorporate in any state, and have that state's corporate law govern the corporation's internal affairs, even the few "mandatory" aspects of corporate law take on a discretionary feel. ${ }^{35}$ This lends support to the view that the corporation is not a product of the state, but rather a product of private agreement. ${ }^{36}$

25. Id. at $417,422-23$.

26. Id. 417-19 (discussing how agency costs explain a number of arrangements between corporate parties).

27. See id. at 453-54 ("[o]nce corporate relationships are conceived as fully voluntary, a different picture of the corporate hierarchy emerges").

28. See Bratton, supra note 18 , at $439-40,457-58$.

29. See id. at $439-40$ (arguing that giving individuals in corporation autonomy to pursue self-interested outcomes allows institutions to function without "deliberate design by higher powers").

30. Katharine V. Jackson, Towards a Stakeholder-Shareholder Theory of Corporate Governance: A Comparative Analysis, 7 HASTINGS BUS. L. J. 309, 335 (2011).

31. See Vasudev, supra note 21, at 923-24 (describing the rise of the law and economics movement and its impact).

32. Bratton, supra note 18 , at 461 .

33. Id.

34. See Melvin Avon Eisenberg, The Structure of Corporation Law, 89 CoLUM. L. Rev. 1461, 1486 (1989) (explaining that corporate statutes are often altered by firms in their charters or bylaws).

35. See Henry N. Butler \& Larry E. Ribstein, Opting Out of Fiduciary Duties: A Response to the AntiContractarians, 65 WASH. L. REV. 1, 10-11 (1990) (describing the various ways in which corporations can avoid certain rules and regulations).

36. See id. 
Perhaps the most significant example of this flexibility is one concerning a bedrock principle of corporate law: fiduciary duty. It is black-letter law that corporate officers and directors are bound by fiduciary duties to serve their corporations loyally and with due care. Nevertheless, in conformity with contractarian thought, Delaware corporate law was amended to permit firms to opt out of the director duty of care in response to a controversial judicial decision in 1985 that aggressively construed the duty. ${ }^{37}$

Whereas the dominant characteristic of the precontractarian firm was the separation of ownership from control, ${ }^{38}$ arguably this has been replaced by a separation of "ownership from ownership" via the ascendancy of institutional investing. ${ }^{39}$ Although scholars have yet to link the development and acceptance of the contractarian model with institutional investing, perhaps there is some connection between these developments. By way of initial observation, for example, the attenuation of ownership through multiple intermediaries (including mutual funds, hedge funds, and pension funds ${ }^{40}$ ) might lend support to the idea that the corporation is not a "thing" capable of being "owned" (a common contractarian critique of property-based models of the firm ${ }^{41}$ ) but rather a legal construct created via contract. As the human element becomes further removed from the corporation, it becomes easier, I suggest, to view the corporation as a mere abstraction.

At the same time, the advent of institutional investors counteracts the dispersion of individual investors that had been the norm during the early twentieth century. ${ }^{42}$ This cuts against the "managerialist" model of the corporation as an institution operated by a largely unchecked management team. ${ }^{43}$

Finally, it can be said that the contractarian model "drew affirmation from the market and the constant rise in share prices" since its general acceptance in the 1980s (a confluence that continued until the financial crisis of 2007) ${ }^{44}$

Since the corporation lacks owners per se, one might wonder about the role of shareholders under the contractarian conceptualization. Contractarians assert that although shareholders do not own the firm, ${ }^{45}$ they are nevertheless treated like owners under corporate law because they have bargained for (or should be deemed to have

37. Id. at 4 (citing Smith v. Van Gorkom, 488 A.2d 858, 864 (Del. 1985)) ("Among other reactions to this case, the Delaware Corporation law, followed by other state statutes, was amended to permit charter amendments opting out of the director duty of care.").

38. See infra note 59 and accompanying text for a discussion of Berle and Means' idea of the separation of ownership from control in the modern corporation.

39. See generally Usha Rodrigues, Corporate Governance in an Age of Separation of Ownership from Ownership, 95 MINN. L. REV. 1822 (2011).

40. See id. at 1830-36.

41. See BAINBRIDGE, supra note 14, at 28.

42. See Michael R. Siebecker, A New Discourse Theory of the Firm After Citizens United, 79 Geo. WASH. L. REV. 161, 181-82 (2010) (noting that institutional investors now own the majority of outstanding stock in American corporations).

43. See infra Part II.A.2 for a discussion of the managerialist view of the corporation.

44. Vasudev, supra note 21, at 914.

45. Cf. id. at 916 (explaining the view that concentrated power among directors undermines the ownership rights of shareholders). 
bargained for) ownership-like rights in the corporation. ${ }^{46}$

As a corollary to this (although not a necessary one), contractarians also generally posit that the corporation is to be managed pursuant to the goal of shareholder wealth maximization. ${ }^{47}$ That is, the directors and officers of the corporation are bound, via fiduciary duty, to manage the corporation with an eye toward maximizing shareholder wealth. ${ }^{48}$ This shareholder wealth maximization objective, in turn, is viewed as part and parcel of the "shareholder primacy norm," which holds, more broadly, that the corporation is to be governed according to the best interests of its shareholders. ${ }^{49}$

\section{Managerialism}

Before the contractarian view of the corporation burst onto the scene, serious inquiry into the nature of the corporation had been fairly dormant for about fifty years. ${ }^{50}$ Indeed, it could be said that, influenced by the "pragmatic instrumentalism" of John Dewey, the dominant mood of corporate scholarship during twentieth century America was "antitheoretical." 51 Pursuant to this utilitarian approach, corporate law was not deduced from a larger theoretical construct, but rather driven by consequentialist concerns. ${ }^{52}$

"Managerialism" best characterizes the dominant understanding of the corporation during this antitheoretical phase..$^{53}$ For during this phase, it was incontrovertible that professionalized, salaried corporate management dominated American business corporations. ${ }^{54}$ And this development had been relatively new. Prior to the twentieth century, corporations were generally smaller, and still often governed by their owners. ${ }^{55}$ Although many years in the making, it is no small coincidence that Adolph Berle and Gardiner Means' famous treatise The Modern Corporation and Private Property, which highlighted the separation of ownership from control as the defining

46. See id. at 918 (discussing how governance and operational issues are determined by contractual methods).

47. See Jackson, supra note 30 , at 336-37 (noting shareholders' incentive to ensure management maximizes firm wealth).

48. See BAINBRIDGE, supra note 14, at 408-10 (contrasting the theory of shareholder wealth maximization with stakeholderism). But see Lyman Johnson, Corporate Law Professors as Gatekeepers, 6 U. ST. THOMAS L.J. 447, 450 (2009) ("no law requires that businesses pursue only the goal of corporate profit or the goal of investor wealth maximization"); Judd F. Sneirson, Green is Good: Sustainability, Profitability, and a New Paradigm for Corporate Governance, 94 IOWA L. REV. 987, 1007 (2009) (finding that socially responsible business practices can be consistent with shareholder wealth maximization).

49. Jackson, supra note 30, at 334. But see Ronald J. Colombo, Ownership, Limited: Reconciling Traditional and Progressive Corporate Law via an Aristotelian Understanding of Ownership, 34 J. CORP. L. 247, 267-68 (2008) (arguing that, under an Aristotelian account of ownership, shareholder primacy does not necessarily entail shareholder wealth maximization).

50. See Michael J. Phillips, Reappraising the Real Entity Theory of the Corporation, 21 FLA. ST. U. L. REV. 1061, 1070 (1994).

51. Id. at $1070,1074-76$.

52. See id. at 1073-77.

53. See William W. Bratton, Jr., The New Economic Theory of the Firm: Critical Perspectives from History, 41 STAN. L. ReV. 1471, 1475-76 (1989).

54. Id. at $1475-76,1487-88$

55. See id. at $1485-87$. 
characteristic of the modern corporation, made its appearance in $1932 . .^{56}$

Although it was clear to all that management dominated the corporation, this descriptive account was not a normatively justifiable one to many. ${ }^{57} \mathrm{~A}$ number of scholars questioned whether management's domination was legitimate, charging that management was operating "without accountability." 58 As discussed, this, in part, accounts for the warm reception that the contractarian model when it appeared in the closing decades of the twentieth century.

\section{Natural Entity Theory}

"Natural entity theory" was the most recent genuine philosophical conceptualization of the corporation to precede the nexus-of-contracts model..$^{59}$ Pursuant to this conceptualization, the corporation is not simply a mere legal fiction, but a genuine article-_"a being with attributes not found among the humans who are its components," ${ }^{20}$ The corporation is thought to be a naturally occurring entitysometimes even described as an "organism." 61 It is seen as a natural outgrowth of human conduct-the product of "the natural activities of private individuals." 62 Natural entity theory was made possible by two developments: the promulgation of general incorporation statutes (which, in a break from past practice, enabled the formation of a corporation via the filing of routine paperwork with one's state), and the rise of "large, management-dominated corporations." ${ }^{63}$

General incorporation statutes sounded the death knell of concession theory-the notion that corporations are creations of the state. ${ }^{64}$ Whereas in years past corporations were chartered on a case-by-case basis, with some scrutiny into their purposes and designs, by the late eighteen hundreds nearly anyone in good standing could incorporate any legitimate business by simply completing and filing the requisite forms. ${ }^{65}$ To the natural entity theorist, the state's issuance of a license to do business as a corporation (following the firm's filing of its articles of incorporation) is not altogether different than the state's issuance of a birth certificate (following the parents' submission of the appropriate documentation). In both cases, the state merely

56. See generally Adolf A. Berle, JR. \& Gardiner C. MEANS, The Modern Corporation ANd PRIVATE PROPERTY (1932).

57. See Bratton, supra note 53, at 1476 (discussing the anti-managerialist view that management did not legitimately hold power over the corporation).

58. E.g., id.

59. See Phillips, supra note 50, at 1067-70 (noting that the real entity theory of corporations preceded the nexus-of-contracts theory). Separating the two theories was the "antitheoretical" period of corporate law (best referred to as "managerialism") that consumed most of the twentieth century. See supra Part II.A. 1. for a discussion of the nexus-of-contracts theory.

60. $I d$. at 1068 .

61. Id. at $1068-69$.

62. David Millon, Theories of the Corporation, 1990 DuKE L.J. 201, 211. Perhaps this view was best captured by Howard Laski, who described the corporation as a "real entity" possessing a "personality that is self-created." Harold Laski, The Personality of Associations, 29 HARV. L. REV. 404, 413 (1916).

63. Phillips, supra note 50, at 1067-70.

64. See infra Part II.A.5 for a discussion of concession theory.

65. See infra Part II.A.5 for a brief discussion of the evolution of the corporate chartering process. 
recognizes the newly formed entity-it does not create it by concession or otherwise. ${ }^{66}$ As Edward Younkins explained: "A corporation is created by, owned by, and operated by a freely constituted group of individuals. The state merely recognizes and records the formation of corporations-it does not bring them into existence." 67

The rise of a class of professional-corporate managers made clear that the corporation was no longer simply a partnership-like association of businesspeople (as "aggregation theory" would hold ${ }^{68}$ ). It was something different-a sui generis entity whose whole was greater than the sum of its parts. ${ }^{69}$ For the corporation "can be substantively distinguished from its owners, managers and employees by its capacity to express independent moral judgments." ${ }^{\text {"Th }}$ That is, through the process of its internal decision-making mechanisms, the corporation can come to a decision that no particular individual would subscribe to individually. And even without the rise of the managerial class, there are certain "qualitative changes people undergo after they enter groups."71 This, by itself, suggests that the corporation is more than simply an aggregation of individuals, as it takes on a certain spirit of its own. ${ }^{72}$

Natural entity theory had important implications for corporate law-many of which worked to decrease the role and reach of state regulation. ${ }^{73}$ The ultra vires doctrine (the doctrine that certain corporate acts exceeded corporate authority) largely withered away during the real entity era, for this doctrine was predicated on the notion that "corporations lacked any powers beyond those conferred by the legislature."74 Similarly, corporations were at one time limited to conducting business within the states of their incorporation under the theory that "corporations could have no power where that law [of their state of incorporation] ceases to operate." This too fell by the wayside during the natural entity era. ${ }^{75}$ By 1910, a business incorporated in one state could conduct business in any other state, reflecting the view that "corporations were

66. See Arthur Machen, Jr., Corporate Personality, 21 HARV. L. REv. 253, 261 (1911) ("A corporation exists as an objectively real entity, which any well-developed child or normal man must perceive: the law merely recognizes and gives legal effect to the existence of this entity."); Susanna Kim Ripken, Corporations are People Too: A Multi-Dimensional Approach to the Corporate Personhood Puzzle, 15 FORDHAM J. CoRP. \& FN. L. 97, 112-13 (2009) (finding that a corporation's existence does not rely on the state's recognition of the corporation).

67. Edward W. Younkins, Morality and Character Development: The Roles of Capitalism, Commerce, and the Corporation, 4 J. MARKETS \& MORALITY 94, 101 (2001).

68. See infra Part II.A.4 for a discussion of aggregation theory.

69. See Brian M. McCall, The Corporation as Imperfect Society, 36 DEL. J. CORP. L. 509, 529-35 (2011) (discussing the historical evolution of modern corporations from the universitas, which was viewed as a whole transcending its members); Millon, supra note 62, at 216 (discussing the theory that corporations as entities exist apart from its ownership).

70. Lawrence Friedman, In Defense of Corporate Criminal Liability, 23 HARV. J.L. \& PUB. POL'Y 833, $848(2000)$

71. Phillips, supra note 50 , at 1108 .

72. See id. at 1108-11 (arguing that the corporation's attributes differ than those of individuals possessed prior to joining the firm).

73. See Millon, supra note 62, at 211-12 (identifying the changing role and reach of state regulations of corporations).

74. Id.

75. Id. 
creations of private initiative, rather than artificial products of state action." ${ }^{276}$ And, as one might expect, the reach of state regulation over corporations was generally pruned back during the natural entity era, and corporations began to increasingly enjoy the rights and status of natural persons, "eliminating the many special limitations on corporate freedom of action that the states had imposed in the past." $" 77$ In short, the corporation was viewed as more of a private entity than a public one ${ }^{78}$

Even the hallmark corporate characteristic of limited liability received explanation and justification from natural entity theory. For if a corporation is seen as an entity distinct from the individuals constituting it, treating it separately and independently for purposes of liability strikes a more sensible chord..$^{79}$

In America, natural entity theory prevailed only briefly-from the late eighteen hundreds to the early nineteen hundreds - sandwiched between managerialism and aggregation theory. ${ }^{80}$ The "pragmatic instrumentalism" that took hold of the American academy by the 1920 s sounded the death knell of serious corporate theory, effectively killing the natural entity conceptualization. ${ }^{81}$ Nevertheless, the theory certainly left an enduring mark on corporate law, ushering in changes that remain in effect long after the theory's demise. ${ }^{82}$

\section{Aggregation Theory}

An important bridge between the foundational concession theory of the corporation $^{83}$ and natural entity theory just discussed is "aggregation theory," which flourished fleetingly during the latter half of the nineteenth century. ${ }^{84}$ Under the aggregation theory, the corporation is neither a state concession nor a separate entityrather, it is simply "an association of individuals contracting with each other" in order to do business together. ${ }^{85}$ Although in its early manifestations this theory focused almost exclusively on the corporation's investors (thereby treating the corporation essentially as a partnership), later manifestations pulled into the "aggregation" other

76. Id. at $212-13$.

77. Id. at 213 .

78. Id.

79. See Lawrence E. Mitchell, Close Corporations Reconsidered, 63 TUL. L. REV. 1143, 1157-58 (1989) (finding that the corporation's independence from its members was "significant to the development of limited liability").

80. Phillips, supra note 50, at 1068-70. See infra Part Il.A.4 for a discussion of aggregation theory. Such is not the case in Europe, where real entity theories of the corporation have a very rich history and lingering vitality as well. 1 JOHN P. DAVIS, CORPORATIONS 242-44 (1905).

81. See supra Part II.A.2 for a discussion of the antitheoretical view of corporations during the twentieth century.

82. See supra notes $73-79$ and accompanying text for a discussion of the influence the natural entity theory had on corporate law.

83. See infra Part II.A.5 for an analysis of the concession theory of corporations.

84. Richard L. Cupp, Jr., Moving Beyond Animal Rights: A Legal/Contractualist Critique, 46 SAN DIEGO L. REV. 27, 55 (2009).

85. Id. (quoting Phillip I. Blumberg, The Corporate Entity in an Era of Multinational Corporations, 15 DEL. J. CORP. L. 283, 293 (1990)). 
corporate constituencies as well. ${ }^{86}$

Although aggregation theory had been articulated by some early in the nineteenth century, its climb to prominence began during the years of the Jackson Presidency. ${ }^{87}$ As already indicated, traditionally corporations were created by specific legislative grants from the state. ${ }^{88}$ The democratization of this process began in earnest during the Jacksonian era, during which a drive was made "to make the general business corporation available to all Americans." 89 As a result, the practice of case-by-case incorporation via specific legislative grants began to be replaced by statutes of general incorporation..$^{90}$ Pursuant to these laws, pretty much any person or persons could create an incorporated business "without a special bill, simply by complying with the statute." 91

Because of the spread of statutes of general incorporation, "corporations no longer seemed a product of sovereign grace," and concession theory lost its hold ${ }^{92}$ A new theory of the corporation was needed, and since "substantial identity still existed between owners and managers" at this time, aggregation theory was a good fit. ${ }^{93}$

Under aggregation theory, the corporation was a legal fiction-a convenient construct to account for the collective action of many private individuals marching under the same banner. ${ }^{94}$ Although aggregation theory toppled concession theory, its reign as champion was short lived. The theory might have persisted longer, but for the advent of a professionalized managerial class that came to control most American corporations near the end of the nineteenth century. ${ }^{95}$ For with this development, "the metaphor of a corporation as an aggregation of partners [had become] less intuitively appealing than it had been in earlier years." $" 96$

As such, the impact of aggregation theory on corporate law is difficult to assess. In many ways, it was a transitional movement toward natural entity theory, and as such can claim credit for much of that theory's achievements or contributions to corporate law. ${ }^{97}$ That is, the ideas that the corporation's powers should not be limited to those granted by the state, that the corporation may do business in states outside of its state of

86. See id. (highlighting aggregation theory's initial focus on shareholders then later expansion to other individuals making up the corporation).

87. Id. at $55-56$

88. Id. at 54. See also supra notes $64-65$ and accompanying text for a discussion of the traditional notion that corporations were created by specific legislative grants by the state.

89. Cupp, supra note 84, at 56 (quoting Jess M. Krannich, The Corporate "Person": A New Analytical Approach to a Flawed Method of Constitutional Interpretation, 37 LOY. U. CHI. L.J. 61, 75 (2005)).

90. See id. (citing Krannich, supra note 89, at 75-76) (arguing that the movement towards general incorporation statutes allowed for corporations to be seen as aggregations of individuals).

91. Franklin A. Gevurtz, Corporation LaW 20-21 (2000).

92. Bratton, supra note 53 , at $1485-86$.

93. Id. at 1485 .

94. See Cupp, supra note 84 , at 55.

95. See id. at 57 (highlighting the increased role of officers and directors, rather than shareholders, in corporate decision making during this period).

96. $I d$.

97. See supra notes 73-79 and accompanying text for a discussion of the contributions and achievements of natural entity theory on corporate law. 
incorporation, and that the corporation should be recognized as a rights-bearing institution-all of these are furthered by the aggregation theory's eclipse of concession theory. ${ }^{98}$

Finally, it must be noted that aggregation theory has arguably been reprised in the nexus of contract model of the corporation. Both view the corporation in "individualist, contractualist" terms-as aggregations "formed by private contracting among its human parts." "99 The primary distinction between the two would be aggregation theory's general focus on shareholders (as akin to partners), versus contractarianism's focus on relationships more broadly.

\section{Concession Theory}

As already mentioned, "concession theory" describes the original understanding of the corporation on American soil-an understanding that reigned supreme from colonial times through the middle of the nineteenth century. ${ }^{100}$ Pursuant to this understanding, "the state was regarded as the creator and master of the corporation, which was simply the servant of the superior will of the state." 101

Concession theory fit well with the historical and factual realities of the eighteenth-century corporation. Unlike their modern counterparts, corporations of that time (and before) "were essentially state chartered monopolies for the pursuit of some interest beneficial to the state." 102 Hence, medieval corporations, and practically all corporations up until the mid-nineteenth century, concerned themselves with undertakings such as education, religion, colonization, foreign trade, bridge-building, hospital maintenance, and other public-oriented activities. ${ }^{103}$ Corporations were chartered by the crown (or, in America, by the state legislature) individually and specifically. ${ }^{104}$ To achieve their ends, corporations were granted certain limited powers

98. See Michael B. Metzger \& Dan R. Dalton, Seeing the Elephant: An Organizational Perspective on Corporate Moral Agency, 33 AM. BUS. L. J. 489, 494-96 (1996) (noting that once incorporation became the right of more than a select few, the state's control over corporations began to diminish).

99. Metzger \& Dalton, supra note 98, at 495-96 (quoting Phillips, supra note 50, at 1065).

100. Liam Seamus O'Melinn, Neither Contract nor Concession: The Public Personality of the Corporation, 74 GEO. WASH. L. REV. 201, 219-20 (2006).

101. Id. at 219.

102. Douglas Arner, Development of the American Law of Corporations to 1832, 55 SMU L. REV. 23, 26 (2002). This is the case with regard to the British experience with corporations-an experience which was exported to North America. Ronald J. Colombo, supra note 49, at 251-52. In contrast, the European continental experience is a more complicated one, which has since ancient times included a strand of thought that equated the corporation as a naturally occurring association of individuals. See Reuven S. Avi-Yonah, The Cyclical Transformations of the Corporate Form: A Historical Perspective on Corporate Social Responsibility, 30 DEL. J. CORP. L. 767, 780-82 (2005) (examining the work of Bartolus regarding ancient European corporations as entities separate from the state and from its members).

103. See Amer, supra note 102, at 26 (explaining how corporations were subordinate institutions serving national purposes); Colombo, supra note 49 , at 251-52 (finding that early nineteenth-century corporations were often established to promote a public purpose such as building banks, churches, or roads); McCall, supra note 69, at 534-35 (describing the social and charitable nature of business entities such as guilds); Brian $M$. McCall, Unprofitable Lending: Modern Credit Regulation and the Lost Theory of Usury, 30 CARDOzo L. REV. 549,599 (2008) (describing the nonbusiness activities of the large eighteenth-century corporations).

104. Arner, supra note 102 , at 37; Colombo, supra note 49 , at 251-52. 
and rights. ${ }^{105}$

Naturally flowing from concession theory were several key aspects of corporate law that have since fallen by the wayside. Since a corporation's existence was dependent upon an exercise of the State's discretion, there was little basis upon which to recognize corporate "rights." 106 Since both a corporation's purposes and the powers it might employ to achieve its purposes were specifically delineated by the State, the doctrine of ultra vires served as a powerful check on corporate activity. ${ }^{107}$

As indicated, by the middle of the nineteenth century, the practice of authorizing corporate charters on a case-by-case basis gave way to laws of general incorporation. ${ }^{108}$ There were a number of reasons for this transition, including the growing demand to conduct business in the corporate form, concerns over corruption associated with the charter-granting process, and the democratic zeitgeist of the Jacksonian Era, which pushed for greater and more equal access to the benefits of incorporation. ${ }^{109}$

\section{B. Modern Corporate Regulatory Diversity}

A review of the unfolding of corporate conceptualizations over time has the effect of marginalizing theories of the past. This is unfortunate because the insights of past conceptualizations remain more relevant today than is commonly acknowledged. For though past conceptualizations have certainly lost their once-held positions of dominance, some of the realities that animated their appearance have not entirely disappeared. In short, although the contractarian conceptualization may best describe most corporations today, it does not as accurately describe them all. Contractarian's dominance is justifiable; its monopoly is not.

Contracterianism fails to conceptually describe all modern corporations, which can vary quite dramatically from one another. ${ }^{110}$ Corporations include entities as diverse as Microsoft, the American Red Cross, the New York Times, the Episcopal Diocese of Albany, the American Civil Liberties Union, the New Jersey Democratic Party, and the Jet Quick Lube Corporation of Hempstead, NY. ${ }^{111}$ Some are large and international, others are small and local. Some are for-profit, others are not-for-profit. Some are religiously oriented, others are politically oriented. Some are publicly traded, others are closely held.

As a result, some of today's corporations are best understood in terms of past

105. See Arner, supra note 102, at 30 (listing certain "automatic incidents" inherent in the creation of a corporation).

106. See Cupp, supra note 84 , at 52 (describing the "artificial" nature of a corporation and detailing how "it possesses only those properties which the charter of its creation confers upon it").

107. Millon, supra note 62 , at 208 . See supra note 78 and accompanying text for a discussion of the decline of the ultra vires doctrine.

108. See supra notes 87-91 and accompanying text for a discussion on the rise of general incorporation.

109. JAMES D. COX \& ThOMAS LeE HAZEN, CoRPORATIONS $\S 2.01$ at 32 (2d ed. 2003); Cupp, supra note 84 , at 56 .

110. See Michael Novak, ON Corporate Governance: The Corporation as It Ought to Be 4 (1997); Bucy, supra note 11, at 1123-27.

111. An independently owned automotive oil change facility on Long Island, N.Y., with a staff of one to four employees. See Jet Quick Lube Corp, MANTA, http://www.manta.com/c/mmzlv73/jet-quick-lube-corp (last visited Oct. 28, 2012). 
conceptualizations. A small family owned and operated corporation, for example, would seem to be well described and understood under the aggregation theory of the nineteenth century-not contractarianism. A large pension fund-and, perhaps, mutual funds in general-might more accurately be envisioned in managerialist terms. A holding company, existing solely on paper and lacking constitutive human members, would appear to be the epitome of an artificial person-perhaps harkening back to concession-theory ideas of the corporation. In sum, although it is certainly permissible to adopt the contractarian model as the default conceptualization of the modern corporation, I suggest that previous conceptualizations be retained and employed as appropriate.

Fortunately, although academics and theoreticians have largely settled upon contractarianism, ${ }^{112}$ lawmakers and regulators do not appear wedded to a universal contractarian conceptualization of the corporation. As has become apparent to them, the fact that a particular entity is a corporation is in many cases neither particularly informative nor particularly noteworthy-other features and characteristics of the entity are far more important depending on the context. Consequently, the manner in which corporations are regulated largely reflects an appreciation of these salient distinctions. What we see time and again is not the law's deference to some overarching conceptualization of the corporation, but rather a tailoring of rules and regulations to the particular business entity before it. In the pages that follow, a few important examples of this practice are discussed.

\section{Corporate Law}

Corporate law itself does not treat all corporations equally. Consider, for example, one of the defining characteristics of the modern business corporation: limited liability. ${ }^{113}$ Called "the greatest single discovery of modern times," 114 limited liability permits a corporation's shareholders to partake in the upside potential of a business venture while risking only the limited sum of their invested capital. ${ }^{15}$

Yet even this comerstone of corporate law is not equally applicable across corporations. Pursuant to the doctrine of "piercing the corporate veil," a corporation's shareholders can be held liable for the debts of the corporation (beyond their total investment amount) if certain features characterize the corporation. ${ }^{116}$ These features primarily include (1) a shareholder's (owner's) failure to observe corporate formalities,

112. Scholars who oppose the nexus-of-contracts model have proposed an alternative theory in its place. E.g., Phillips, supra note 50, at 1063 (arguing in favor of the real entity theory).

113. See Robert CLARK, CORPORATE LAW $\S 1.1$, at 2 , $\$ 1.2$ at 7-10 (1986) (summarizing the benefits provided by limited liability arrangements); Daniel J. Morrissey, Piercing All the Veils: Applying an Established Doctrine to a New Business Order, 32 J. CORP. L. 529, 534-36 (2007) (quoting Nicholas Murray Butler, President, Columbia Univ., Address at the 143rd Annual Banquet of the Chamber of Commerce of the State of New York (Nov. 16, 1911)) (tracing the historical context of limited liability).

114. Morrissey, supra note 113, at 534-35 (quoting Butler, supra note 113). Butler further explained that "even the steam engine and electricity are far less important than the limited liability corporation and they would be reduced to comparative impotence without it." Butler, supra note 113.

115. Morrissey, supra note 113 , at 536.

116. See CoX \& HAZEN, supra note 109, at 106-11 (describing several bases for piercing the corporate veil). 
(2) a shareholder's (owner's) domination of corporate affairs, and (3) inadequate corporate capitalization. ${ }^{117}$ When these features are present (and especially if they are present in combination), courts may choose to discard the rule of limited liability and hold shareholders accountable for a corporation's debts. ${ }^{118}$

The veil piercing doctrine does not appear consistent with a contractarian view of the corporation, for a number of reasons. ${ }^{119}$ For example, veil piercing clings to the notion that the corporation is a "thing" that is actually owned by somebody (the shareholders). ${ }^{120}$ It also reads into the corporate nexus contractual terms that are not necessarily justifiably inferred. The heavy-handedness of this imposition harkens back, I suggest, to the concession theory of the firm more than any other. Regardless of the doctrine's propriety, however, the important point to be grasped is that veil piercing handles different incorporated business entities differently. Veil piercing is an example of the law's ability and practice to look beyond the mere nomenclature of a firm and into its substantive characteristics in assessing how best to treat that firm.

Another common example is that of the "close corporation."121 These entities share little in common with most other, public corporations, even though they are ordinarily incorporated under the same statutes of general incorporation. ${ }^{122}$ Most significantly, close corporations "have only a small number (for example, fewer than thirty) of individual shareholders and [their] shares are not traded on a recognized securities exchange or on the over-the-counter market." 123 This lack of liquidity, coupled with the active management of the enterprise by its shareholders (which is often the case), gives rise to a host of characteristics at odds with the prevailing corporate paradigm. ${ }^{124}$ In recognition of this, the law treats close corporations differently than public corporations. ${ }^{125}$ Not all the same corporate formalities need to be observed, restrictions on share transferability are more likely to be enforced, and even restrictions on director discretion have been upheld. ${ }^{126}$ Although this is largely a matter of case law, formal distinctions are also apparent in state codes as well. ${ }^{127}$

117. See id. (explaining how these three features manifest themselves in practice).

118. Id. at 104 .

119. That said, to the extent that contractarianism is an offshoot of aggregation theory, veil piercing could be conceptually justified. Simply put, veil piercing could be said to recognize the existence and responsibility of real entities behind the non-entity of the contractarian corporation. See infra note 153 and accompanying text for a description of the relationship between contractarianism and aggregation theory.

120. See Stephen M. Bainbridge, Abolishing Veil Piercing, 26 J. CORP. L. 479, 515 (2001) (explaining how veil piercing affects limited liability, and why veil piercing is inconsistent with contractarianism).

121. See Mitchell, supra note 79, at 1144.

122. CLARK, supra note $113, \S 1.3$, at 24-25.

123. Id. at 24 .

124. See id. $\S 1.3$, at 26 (noting that the "roles of investor and manager or employee" are often blurred in close corporations).

125. See id. at 28.

126. See id. $\S \S 18.1-18.2$, at $763-84$ (providing a detailed discussion of various restrictions imposed upon close corporations).

127. Id. $\S 1.3$, at 28 . 
2. Securities Regulation

An important subset of corporate law, federal securities regulation, also (repeatedly) takes into account the diversity that marks corporate entities.

Federal securities law distinguishes those corporations that are "public" (or "reporting") from those that are "nonpublic" (or "nonreporting"), and significant repercussions follow this categorization. ${ }^{128}$ Public companies are (subject to some exceptions) those corporations that (a) have made a public offering of securities; (b) have securities listed on a national stock exchange; or (c) have more than $\$ 10$ million in total assets and more than 500 equity shareholders. ${ }^{129} \mathrm{~A}$ public company is subject to a panoply of disclosure requirements, including annual reports, quarterly reports, proxy statements, and other reports triggered by the occurrence of certain specified events. ${ }^{130}$

The Securities and Exchange Commission (SEC) distinguishes public from nonpublic companies in recognition of their different cost sensitivities, and the divergent needs of the investing public when it comes to such companies. ${ }^{131}$ Corporations whose securities are not publicly traded, who have few securities holders (less than 500), and who fall below the $\$ 10$ million asset level are simply deemed (as a matter of rough approximation) less capable of handling the cost and expense of the law's mandatory disclosure regime. ${ }^{132}$ Additionally, the informational needs of the investing public with respect to such corporations are considered to be diminished.

An even more elaborate set of distinctions applies to issuers who wish to make a public offering of securities. The SEC divides these corporations into four different categories: (1) unreporting issuers, (2) unseasoned issuers, (3) seasoned issuers, and (4) well-known seasoned issuers. ${ }^{133}$

A host of repercussions follow an issuer's categorization within the scheme set forth above. ${ }^{134}$ As one moves from the first category (unreporting issuers) to the fourth (well-known seasoned issuers), one moves from corporations that are not publicly traded, to corporations that are heavily capitalized capital-market veterans. ${ }^{135}$ Along the way, one discovers greater privileges and flexibility being afforded to the issuing corporation in terms of required disclosures. ${ }^{136}$ The logic behind this scheme is that the

128. Amy Deen Westbrook, Sunlight on Iran: How Reductive Standards of Materiality Excuse Incomplete Disclosure Under the Securities Laws, 7 Hastings BuS. L.J. 13, 20 (2011).

129. MARC I. SteinBerg, UNDERSTANDING SeCURITIES LAW 476 (4th ed. 2007); Westbrook, supra note 128 , at 20 .

130. Westbrook, supra note 128 , at 20-21.

131. Cf. Relief from Reporting by Small Issuers, Exchange Act Release No. 34-37157, 61 SEC Docket 2092 (May 1, 1996) (altering public securities regulation in order to shield smaller businesses from federal securities regulations).

132. Cf. id. (explaining that increasing the asset level for small businesses to ten million is still consistent with investor protection).

133. Securities Offering Reform, Securities Act Release No. 33-8591, Exchange Act Release No. 52,056, Investment Company Act Release No. 26,993, 70 Fed. Reg. 44,722, 44,734 (Aug. 3, 2005).

134. See STEINBERG, supra note 129, at 117 (explaining some differences in SEC regulations based on a corporation's categorization).

135. Securities Offering Reform, Securities Act Release No. 33-8591, Exchange Act Release No. 52,056, Investment Company Act Release No. 26,993, 70 Fed. Reg. 44,722, 44,734 (Aug. 3, 2005).

136. Id. at 44,726 n. 40 . 
investing public needs greater disclosure when it comes to the securities of poorlyknown companies, and lesser disclosure when it comes to the securities of well-known companies. ${ }^{137}$ Again we witness the law's ability and tendency to look beyond the mere fact of incorporation, and predicate its impositions upon other characteristics (in this case, social realities).

\section{Employment Law}

Title VII of the Civil Rights Act of 1964 famously prohibits any employer to discriminate against any employee on the basis of race, sex, color, or national origin. ${ }^{138}$ Title VII defines an "employer" as:

[A] person engaged in an industry affecting commerce who has fifteen or more employees for each working day in each of twenty or more calendar weeks in the current or preceding calendar year, and any agent of such a person, but such term does not include (1) the United States, a corporation wholly owned by the Government of the United States, an Indian tribe, or any department or agency of the District of Columbia subject by statute to procedures of the competitive service (as defined in section 2102 of Title 5), or (2) a bona fide private membership club (other than a labor organization) which is exempt from taxation under section 501(c) of Title 26, except that during the first year after March 24, 1972, persons having fewer than twentyfive employees (and their agents) shall not be considered employers. ${ }^{139}$

Observe how the definition turns not on whether the entity is incorporated or not, but instead primarily upon the entity's size-_"fifteen or more employees." 140 Similarly, when it comes to punitive damages, Title VII requires the courts to consider the size and financial capacity of the defendant. ${ }^{141}$ Further still, the Act places statutory caps on the award of punitive damages based on the size of the employer in terms of its number of employees. ${ }^{142}$ Thus, when it comes to employment law, a business's size is what matters; the fact that a business may be incorporated or not is wholly irrelevant. ${ }^{143}$

\section{Formal Distinctions}

Perhaps the most visible way in which corporations have come to be recognized as differing from one another is via statutory categorization. Over the years, a multiplicity of corporate variations have come to be recognized, and someone wishing to incorporate an entity today has an ever-growing list of corporate forms to choose from.

The most significant legally recognized distinction is that between for-profit and

137. Id. at 44,727 .

138. Civil Rights Act of 1974, Pub. L. No. 88-352, 78 Stat. 241 (codified as amended at 42 U.S.C. $\S 2000 \mathrm{e}$ ); 3C KeVIN F. O'MALleY, ET AL., FEDERAL JURY PRACTICE AND INSTRUCTION 160 (5th ed. 2001).

139. 42 U.S.C. $\S 2000 \mathrm{e}(\mathrm{b})(2006)$.

140. Id.

141. 45C AM. JUR. 2D Job Discrimination $§ 2661$ (2012).

142. 42 U.S.C. $\S 1981 \mathrm{a}$.

143. The same holds true with regard to the Patient Protection and Affordable Care Act, Pub. L. No. $111-148,124$ Stat. $119(2010)$, the applicability of which turns on the size of the business in question, see 1 RONALD J. COOKE, ERISA PRACTICE AND PROCEDURE $\S 1: 101$ (2012). 
not-for-profit corporations. The fundamental difference between these two entities has been well explained by Henry Hansmann:

The defining characteristic of a nonprofit organization is that it is barred from distributing profits, or net earnings, to individuals who exercise control over it, such as its directors, officers, or members. This does not mean that a nonprofit organization is prohibited from earning a profit. Rather, it is only the distribution of profits that is prohibited; net income, if any, must be retained and devoted to the purposes for which the organization was formed. Moreover, it is only net income, or pure profits, that may not be distributed; nonprofits are generally free to pay reasonable compensation to individuals, including controlling individuals, for labor services or capital provided to the organization. ${ }^{144}$

Not surprisingly, therefore, the law treats nonprofit corporations differently than for-profit corporations in many significant ways. ${ }^{145}$ One obvious difference is the ability of certain nonprofit corporations to avoid the payment of income taxes. ${ }^{146}$

Further variations in the types of corporations that can be created have been promulgated, which in some ways blurs the traditional aforementioned distinction between for-profit and not-for-profit. In New York State, for example, one can choose to incorporate as a business corporation, a nonprofit corporation, a cooperative corporation, a religious corporation, a transportation corporation, or (as of 2012) a benefit corporation. ${ }^{147}$ And with each choice comes a particularized set of default (and sometimes mandatory) governing rules. ${ }^{148}$ The choice is not carte blanche, of coursethe options available will depend upon the characteristics of the organization in question. But this growing list of choices underscores the fact that for many corporations, what they have in common (a shared corporate form) is less important than what distinguishes them (e.g., their for-profit or not-for-profit nature).

\section{CORPORATE PERSONHOOD AND RIgHTS}

Having examined the nature of the corporation vis-à-vis society in Section II of this Article, I shall now examine the nature of the corporation vis-à-vis the United

144. Henry B. Hansmann, Reforming Nonprofit Corporation Law, 129 U. PA. L. REv, 497, 501 (1981).

145. See id. at 501-08 (providing examples of unique legal treatment of nonprofit corporations).

146. 16 Eugene MCQuillin, The LaW of Municipal Corporations $\S 44.76 .10$ (Dennis Jensen \& Gail A. O'Gradney eds., 3d ed. 2003).

147. See Andrew Delmonte, New York State Senate and Assembly Pass Benefit Corporation Legislation, BUFFALO RISING (June 28, 2011) http://www.buffalorising.com/2011/06/new-york-state-senate-and-assemblypass-benefit-corporation-legislation.html (describing legislation involving "benefit corporations" in New York). See generally N.Y. Bus. CORP. LAW $\S 201$ (McKinney 2012); N.Y. NOT-FoR-ProfIT CORP. LAW § 201; N.Y. COOP. CORP. LaW $\S 13$; N.Y. Relig. CorP. LaW $\S 2$; N.Y. TransP. CoRP. LaW $\S \S 2$, 3. Seven states in total permit businesses to incorporate as "benefit corporations"-New York, New Jersey, California, Maryland, Vermont, Virginia, and Hawaii. Angus Loten, With New Law, Profits Take Back Seat, WALL ST. J., Jan. 19, 2012, at B1.

148. Compare N.Y. RELIG. CORP. LAW $\S 2$ (providing the requirements to incorporate as a religious corporation), with N.Y. TRANSP. CORP. LAW $\S 2$ (providing the requirements to incorporate as a transportation corporation). 
States Constitution. This sets the stage for Section IV, which will bring together these natures, and consider them in light of the political philosophy of Alexis de Tocqueville.

\section{A. The Corporation as a Rights-Bearing Person}

As discussed, changes in corporate theory have largely matched the evolving realities of the corporation. ${ }^{149}$ (The most important inflection points along the way would appear to be the advent of statutes of general incorporation (which spelled the demise of concession theory), ${ }^{150}$ and the separation of ownership from control (which ushered in corporate law's modern era, marked by managerialism and contractarianism) ${ }^{151}$ ).

Proceeding simultaneously has been the advance of corporate constitutional rights, and the related development of "corporate personhood."152 Curiously, however, these two interrelated phenomena have not closely tracked the path that corporate theory cut, nor the evolving realities of the corporate form. Instead, these two interrelated phenomena have generally operated along their own trajectory, marching to the beat of their own drums. ${ }^{153}$ In fact, for the most part, this development has been untheorized, and unmoored to the reality (or understanding) of the corporation itself.

Corporate personhood refers to the fact that "the law conceives corporations to be legal persons with certain powers and purposes." 154 One might expect the concept of corporate personhood to manifest itself differently depending upon an era's overall conceptualization of the corporation. For example, the apogee of corporate personhood might logically be expected in the concession-theory era, when the corporation was seen as nothing other than a legal fiction. On the other hand, one might expect the concept of corporate personhood to be used for the sake of convenience in the periods of aggregation theory, or its descendant, contractarianism, where there is simply an aggregation of individuals.

Similarly, the apex of corporate personhood might logically be expected in the

149. See supra Part II.A for a discussion of changes in corporate theory.

150. See supra notes 90-91 and accompanying text for the historical context of general incorporation statutes.

151. See supra notes 54-56 and accompanying text for a discussion of the key characteristics of modern corporations.

152. By corporate constitutional rights, I mean the courts' recognition of constitutional rights applicable to corporations; by corporate personhood, I mean the courts' recognition of the corporation as a "person" capable of possessing constitutional rights.

153. See David Graver, Comment, Personal Bodies: A Corporeal Theory of Corporate Personhood, 6 U. CHI. L. SCH. RouNDTABLE 235, 236 (1999) (providing an overview of the Court's jurisprudence on corporate rights vis-à-vis corporate personhood). But see Stephen G. Wood \& Brett G. Scharffs, Applicability of Human Rights Standards to Private Corporations: An American Perspective, 50 AM. J. СомP. L. SUPP. 531, 540-41 (2002) (arguing that "the choice of theory affects the content and scope of rights and duties assigned to the corporation"). I acknowledge that the way in which a corporation is theorized can influence the rights that are granted to the corporation. Indeed, I believe that it should influence the question of rights. I observe, however, that the historical linkage between theory and rights is a weak one at best. Thus, I disagree with Wood and Scharfs' assertion that the "content and scope of the rights and duties of corporations have developed over the years in response to evolving theoretical understandings of the nature of the corporate persona." $I d$. at 541.

154. CLARK, supra note $113, \S 16.1$, at 675 . There are a number of issues with "corporate personality." See id. at $675-76$. 
real-entity era, when the corporation was seen as a naturally occurring feature of human society. But this is not the case. As Michael Phillips has observed: "Historically, there seem to be few clear links between the real entity theory and the emergence of corporate legal rights." ${ }^{155}$ Generally speaking, the concept of corporate personhood has grown steadily in robustness over time, despite the more checkered evolution of corporation theory itself-including the abandonment of real-entity theory.

Given the movement away from real-entity theory into the managerialist era, to the modern contractarian conceptualization, one might have expected the idea of corporate personhood to wane. After all, the movement from a naturally-occurring real entity, to an untheorized legal fiction, to the nothingness of a nexus, would suggest, I posit, a move away from the personalization of the corporation-a move away from notions of corporate personhood (and, concomitantly, corporate rights). But this is not what happened. Instead, the robustness of corporate personhood has waxed largely unabated.

Ironically, it was during the concession-theory era that the movement to recognize corporate rights and personhood received its first substantial impetus in America. In 1819, Chief Justice Marshall penned the decision Trustees of Dartmouth College $v$. Woodward ${ }^{156}$ upholding the rights of corporations against the powers of the state. ${ }^{157}$ The right in question in Dartmouth College was the simple right of a corporation to enjoy its corporate charter free of postincorporation impairment by the very state that had granted it. ${ }^{158}$ But this was a start. And with the exception of a brief detour in 1839, when the Supreme Court declared that the corporation was not a "citizen" within the meaning of Article IV of the U.S. Constitution, ${ }^{159}$ the growth in recognizing corporate personhood and rights proceeded steadily. ${ }^{160}$

Perhaps influenced by the real entity theory of his time, in 1886 Chief Justice Waite famously declared to counsel about to argue before the Court:

The court does not wish to hear argument on the question whether the provision in the Fourteenth Amendment to the Constitution, which forbids a State to deny to any person within its jurisdiction the equal protection of the laws, applies to these corporations. We are all of the opinion that it does. ${ }^{161}$

I say "perhaps influenced" because the Court did not explain how it came to this unanimous conclusion-neither from the bench nor in its opinion. ${ }^{162}$ And in the years that followed, the explanations that were forthcoming were both meager and unclear. ${ }^{163}$

155. Phillips, supra note 50 , at 1098.

156. 17 U.S. 518 (1819).

157. Woodward, 17 U.S. at 650.

158. Id. at 624 .

159. Bank of Augusta v. Earle, 38 U.S. 519, 520 (1839) (explaining that a corporation has "no legal existence" outside the state of incorporation); see also Elizabeth Pollman, Reconceiving Corporate Personhood, 2011 UTAH L. REV. 1629, 1636-37 (2011) (explaining the gradual movement from the corporation as an artificial being to its current status as a natural person).

160. For an excellent catalogue of corporate rights, constitutional and otherwise, see Wood \& Scharffs, supra note 153 , at 547-65.

161. Santa Clara Co. v. S. Pac. R.R., 118 U.S. 394, 396 (1886).

162. Pollman, supra note 159 , at 1644.

163. See id. at 1645-46 (explaining that although Santa Clara was affirmed as precedent in other cases, 
To the extent that a consistent line of reasoning can be discerned, one could say that the Court recognized corporate personhood (and, with it, certain rights) out of a concern over the property rights of corporate shareholders. ${ }^{164}$

Perhaps discernment of this Santa Clara reasoning holds the key to understanding why corporate theory, and corporate rights, proceeded along different paths. Whereas the changes in corporate theory were pegged to changing corporate realities, changes in the Court's treatment of the corporation were pegged primarily to changing understandings of the U.S. Constitution. ${ }^{165}$ For the period of ascendency for corporate rights occurred within the same period during which the Supreme Court increasingly read the U.S. Constitution to protect economic rights and interests generally. ${ }^{166}$ This development need not be, and apparently was not, related to the realities of the corporate form or the nuances of corporate theory.

This explanation would also help illuminate why the advance of corporate rights and personhood continued throughout the managerial era-a time when corporate theorizing was basically dormant. ${ }^{167}$ As Elizabeth Pollman explains, "the twentieth century staged a significant expansion of corporate rights beyond this [economic] context," but without articulating "a coherent concept of corporate personhood."168 And although, during the first half of the managerial era, the Supreme Court would occasionally make mention of corporate theory in its decisions regarding corporate rights, by 1960 the Supreme Court avoided such discussions altogether. ${ }^{169}$ By 1960 , it had become quite clear that the Court's focus was on the Constitution and the particular constitutional right in question-not on corporate theory. ${ }^{170}$ This focus is quite clear in the Supreme Court decision at the heart of this Article: Citizens United.

Citizens United concerned a challenge to the McCain-Feingold Bipartisan Campaign Reform Act of 2002 (the Act). ${ }^{171}$ The Act, in relevant part, prohibited a corporation from using its general treasury funds to engage in "electioneering communication" within thirty days of a primary election, or sixty days of a general election. ${ }^{172}$ In a five-four decision authored by Justice Kennedy, the Supreme Court struck down that portion of the Act. ${ }^{173}$ Nowhere in the decision does Justice Kennedy invoke a conceptualization of the corporation, or address the nature of the corporation. Instead, his analysis focuses solely on the First Amendment to the Constitution. ${ }^{174}$

its reasoning was never fully analyzed).

164. Id.

165. See TRIBE, supra note 10, at 567-74 (discussing the Lochner era of Constitutional interpretation).

166. $I d$.

167. See supra Part II.A.2 for a discussion of the managerial era.

168. Pollman, supra note 159 , at 1647.

169. See Graver, supra note 153, at 240 (pointing out that since 1960, the Supreme Court has stopped theorizing about corporations altogether).

170. See Elizabeth Salisbury Warren, The Case for Applying the Eighth Amendment to Corporations, 49 VAND. L. REV. 1313, 1320 (1996) (noting that in 1960 the Court stopped addressing corporate personhood and instead focused solely on the amendment that spawned the constitutional issue).

171. Pub. L. No. 107-155, 116 Stat. 81 (2002) (codified primarily in scattered sections of 2 U.S.C.).

172. Citizens United v. Federal Election Commission, 130 S. Ct. 876, 887 (2010).

173. Id. at 917.

174. See id. at 896-97 (discussing principles underlying the First Amendment and citing laws found to 
Simply put, the Court finds that Congress has no power to regulate political speechregardless of the speaker. ${ }^{175}$

The lengthy dissent, authored by Justice Stevens, argued in favor of the Act's validity on a number of grounds. ${ }^{176}$ Stevens, however, not only failed to invoke a conceptualizion of the corporation, but explicitly disavowed the importance of theory altogether: "Nothing in this analysis turns on whether the corporation is conceptualized as a grantee of a state concession, ... a nexus of explicit and implicit contracts, . . a a mediated hierarchy of stakeholders, ... or any other recognized model." 177 Thus, in Citizens United, we are treated to a discussion of the First Amendment's application to corporations, entirely devoid of any serious analysis of the theoretical nature of corporations.

Observing that a segment of the Supreme Court's constitutional jurisprudence rests upon an undertheorized conceptualization of the corporation does not necessarily call into question the wisdom or validity of that jurisprudence. ${ }^{178}$ For corporate law and constitutional law are two distinct fields. The outer limits of what the Constitution enables corporations to do or enjoy need not be coterminous with the privileges and rights afforded to corporations under their state charters. Indeed, it should not be. For the focus of constitutional law is on the powers and limitations of the U.S. federal government. By contrast, state corporate law focuses on the fundamental powers and structure of a private entity-the corporation. ${ }^{179}$

That said, corporate powers not heretofore recognized under the U.S. Constitution invite the reexamination of state corporate law. As such, the breadth of corporate free speech rights articulated in Citizens United invites us to reconsider the degree to which state corporate law facilitates the ability of corporations to engage in political speech. Now that federal limitations on such speech are largely off the table, ${ }^{180}$ it is incumbent upon state lawmakers to weigh the merits of allowing incorporated entities to operate

be unconstitutional restrictions of speech).

175. See id. at 899 (finding "no basis for the proposition that, in the context of political speech, the Government may impose restrictions on certain disfavored speakers"). The Court simply assumes, without any discussion, that corporations are capable of "speaking."

176. See id. at 929-80 (Stevens, J., concurring in part and dissenting in part) (emphasizing the distinction between corporations and people as speakers and the need to prevent corporations from undermining the self-government tradition of the United States).

177. Id. at $971 \mathrm{n} .72$ (citations omitted).

178. Of course, this argument can certainly be made. See, e.g., Katie J. Thoennes, Frankenstein Incorporated: The Rise of Corporate Power and Personhood in the United States, 28 HAMLINE L. REV. 203, 229-32 (2005) (highlighting inconsistent interpretations of the Fourteenth Amendment suggesting constitutional protections should not be afforded to corporations).

179. CoX \& HAZEN, supra note 109, at 31-36.

180. That said, some in Congress have pushed for legislation that would purportedly circumvent Citizens United, and some have even called for a constitutional amendment to reverse the decision. See Dan Eggen, Did Citizens United Ruling Create a Monster?, WASH. POST, Jan. 19, 2012, at A13 (describing grassroots efforts aiming to amend the U.S. Constitution); Sam Favate, Udall: Amend the Constitution, Wipe Out Citizens United, WSJ LAW BLOG (Nov. 2, 2011, 12:51 PM), http://blogs.wsj.com/law/2011/11/02/udall-goes-nuclearproposes-amendment-to-wipe-out-citizens-united/?blog_id=14\&post_id=41 182 (describing one U.S. Senator's efforts to amend the U.S. Constitution and thereby reverse Citizens United). 
so unimpeded. ${ }^{181}$ And it is at the state level that corporate theory and examination of corporate realities ought to most heavily influence policymaking.

\section{B. Matching Rights with Theory}

In light of the preceding, any attempt to evaluate the propriety of corporate free speech rights should do so within the proper theoretical context. Given that the nexusof-contracts understanding of the corporation reigns supreme today, one would expect reference to that conceptualization in weighing the merits of corporate free speech. ${ }^{182}$ Not surprisingly, this is what leading corporate scholars have done. ${ }^{183}$

But, as previously discussed, the contractarian understanding does not accurately describe every corporation currently in existence. ${ }^{184}$ Other, older conceptualizations are sometimes a better fit, due to the particularities of a given corporate entity. This suggests that we ought to evaluate the propriety of recognizing First Amendment protections not simply within the context of the contractarian conceptualization, but under each potential conceptualization. Once we have determined which conceptualization(s) can justify the extension of free speech rights to the corporation, we can then determine whether a given corporation should possess such rights by simply determining which conceptualization best describes it. ${ }^{185}$

I suggest that the conceptualization which most justifies recognition of corporate free speech rights is the aggregation theory. The remaining conceptualizations, in order of decreasing justifiability, are as follows: real-entity theory, contractarian theory, and concession theory.

Aggregation theory posits that the corporation is essentially an aggregation of individuals-not unlike a partnership. ${ }^{186}$ And there is little reason to suggest that the unquestionable right to free speech possessed by individuals vanishes once these individuals combine to form a partnership. ${ }^{187}$ The critical question concerns what happens if this partnership decides to incorporate. If very little happens in terms of the substantive reality of the entity - if the only change is "on paper" so to speak-it would

181. See supra note 8 for a description of ways states may restrict corporations' rights.

182. See supra note 14 for a description of early works advancing the nexus-of-contracts approach.

183. E.g., Stephen Bainbridge, Citizens United, Corporate Personhood, and Nexus of Contracts Theory, ProfessorBainBridge.COM (Jan. 21, 2010, 3:30 PM), http://www.professorbainbridge.com /professorbainbridgecom/2010/01/citizens-united-corporate-personhood-and-nexus-of-contracts-theory.html.

184. See supra Part II.B for examples of corporations that are better understood under the aggregation, managerialist, or concession theories.

185. This is, of course, directly contrary to the approach taken by the Supreme Court, which "rejects the idea that different entities, including different types of corporate entities, can have different rights and different roles in campaign finance." Frances R. Hill, Exempt Organizations in the 2008 Election: Will Wisconsin Right to Life Bring Changes?, 19 U. FLA. J.L. \& PUB. POL'Y 271, 292 (2008). But, as discussed, the subject of our inquiry is not rights afforded by the Constitution, but rather the justifiability of empowering corporations to partake in those rights pursuant to state corporate law.

186. See supra Part II.A.4 for a discussion of the similarity between partnerships and aggregation theory's perception of corporations.

187. See Carol R. Goforth, "A Corporation Has No Soul"-Modern Corporations, Corporate Governance, and Involvement In The Political Process, 47 Hous. L. REv. 617, 654 n.186 (2010) (arguing that partnerships may actually further free speech interests for their individual members). 
seem as though this entity should not be stripped of its free-speech rights merely because it filed articles of incorporation. ${ }^{188}$

Oftentimes, however, much does change after incorporation. Outside investors may be added to the mix. With the ability to raise additional capital more easily, corporations often expand in size, and outgrow their earlier management team. ${ }^{189}$ These changes suggest the inapplicability of the aggregation theory-and a segue to realentity theory.

For at this point, the enterprise takes on a character qualitatively different than that of a partnership. The admixture of outside investors and professionalized management transforms the entity into something other than an assemblage of "partners." Roles and hierarchies develop, such that the enterprise can be said to take on a life of its own. ${ }^{190}$

But just because the enterprise might now be considered a "real entity," it does not ineluctably follow that the entity should be endowed with free speech rights. There are many "real entities" in this world, from tadpoles to trees, none of which enjoy constitutional rights or constitutional personhood. ${ }^{191}$ Nevertheless, the symbolism of real-entity status is indeed suggestive of "drives and interests that the law might sometimes be obligated to respect." 192 Thus, in assessing the relative strength of their claims to constitutional rights, I would place those corporations best theorized as "real entities" second on the list of rights-deserving corporate enterprises. Not as entitled to rights in the same way as actual human beings are entitled when aggregated together, but arguably entitled to rights as the natural, real product of human effort.

The remaining theories-contractarianism and concession ${ }^{193}$-are distinctively less supportive of free speech rights. For under such theories, the corporation is explicitly a legal fiction. ${ }^{194}$ Moreover, it is either a legal fiction instituted to further

188. Some have suggested that the "mere" act of incorporation brings with it tremendous benefits and advantages (such as the protections of limited liability), and that this justifies certain restrictions on a corporation's constitutional rights. E.g., Jill E. Fisch, Frankenstein's Monster Hits the Campaign Trail: An Approach to Regulation of Corporale Political Expenditures, 32 WM. \& MARY L. REV. 587, 630-31 (1991). But as Richard Epstein has pointed out, constitutional rights cannot be denied solely because an individual or entity has lawfully availed himself, herself, or itself of legal rights and privileges. Richard A. Epstein, Citizens United v. FEC: The Constitutional Right That Big Corporations Should Have But Do Not Want, 34 HARV. J.L. \& PUB. POL'Y 639, 647 (2011).

189. See Lawrence E. Mitchell, Close Corporations Reconsidered, 63 TuL. L. REv. 1143, 1189 (1989) (suggesting that firms seeking large amounts of capital will be inclined to incorporate in order to retain centralized control and attract large investments).

190. See Phillips, supra note 50, at $1067-68$.

191. Cf. Charles I. Lugosi, If I Were a Corporation, I'd Be a Constitutional Person, Too, 10 TEX. REV. L. \& POL. 427, 428 (2006) (questioning why a corporation acquires constitutional rights but an unborn child does not).

192. Phillips, supra note 50, at 1097-98.

193. Managerialism is not considered because it is the absence of theory. See supra Part II.A.2 for an analysis of managerialism. Moreover, corporations that can be described as fitting the managerialist model can most likely be categorized under real-entity theory or contractarianism, depending on their specific characteristics. fictions.

194. See supra Parts II.A.1 and II.A.5 for a discussion of viewpoints that see corporations as legal 
public policy, as in the case of concession theory, ${ }^{195}$ or to further private profit, as is the assumption under contractarianism. ${ }^{196}$ Given the role and purpose of freedom of speech in our society, ${ }^{197}$ neither conceptualization of the corporation provides a particularly compelling basis upon which to recognize corporate free speech rights carte blanche. ${ }^{198}$

In sum, those corporations that would be best characterized as aggregates or real entities possess the strongest claim to the protections of the First Amendment. Those for whom the contractarian or concessionary model serves as a better fit appear to hold much weaker claims. As the question is one of propriety and wisdom, and not one of constitutional right (for that was settled by Citizens United), state legislatures would be the most appropriate bodies for making the distinctions needed to implement such a dichotomy. ${ }^{199}$

The preceding survey of corporate free speech rights in light of the various historical corporate theories was brief, but intentionally so. ${ }^{200}$ This brevity is due to an important observation made by Susanna Ripken regarding the nature of the modern corporation. For whereas I have argued that no one conceptualization ought to monopolize the field in terms of describing the modern business corporation, Ripken has gone one step further, observing that we should eschew even pigeonholing individual corporations into one of the theoretical boxes of corporate conceptualization. ${ }^{201}$ As Ripken explains, the modern corporate entity is an "incredibly complex" institution with a "multi-faceted nature."202 No one conceptualization does it

195. See Phillips, supra note 50, at 1064-65 (stating that during the early nineteenth century, corporations were usually chartered so as to link them to some public purpose).

196. See id. at 1073 (arguing that under contractarianism, corporations can be seen as "rational utility maximizers of economic theory").

197. See infra Part IV.C for a discussion of critiques of corporate free speech rooted in the values free speech is intended to promote.

198. To the extent that the contractarian model is viewed as simply the modern manifestation of the earlier aggregation-theory model, a different assessment may be in order. See supra Part II.A.4 for a discussion of aggregation theory. For if a contractarian corporation is merely the aggregation of individuals via contract, an argument could be made that such an entity is deserving of First Amendment rights along the very same lines used to justify such rights within the context of aggregation-theory corporations. See supra notes 186-88 and accompanying text for a discussion of aggregation theory and corporate free speech theory. In this Article, I am crediting contractarian rhetoric, which ordinarily resists efforts to "reify" the corporation, and instead insists on its fictional, abstract nature. E.g., Henry N. Butler \& Larry E. Ribstein, Opting Out of Fiduciary Duties: A Response to the Anti-Contractarians, 65 WASH. L. REV. 1, 3 n.1 (1990). This rhetoric, I suggest, undermines claims to First Amendment rights.

199. A federal judicial role could be foreseen in protecting one state's determination in these matters against another's, by recognizing a state's limitations on corporate speech as applicable to foreign corporations (corporations chartered in another state). This would be an encroachment upon the internal affairs doctrine. See STEPHEN M. BAINBRIDGE, CORPORATE LAW 8 ( $2 \mathrm{~d}$ ed. 2009) (arguing the usefulness of the corporation's legal personhood). However, such an encroachment would not be without precedent. See Jason S. Haller, The Constitutionality of Outreach Statutes Under the Dormant Commerce Clause, 37 SETON HALL L. REV. 597, 598 (2007).

200. I warmly invite and encourage others who are so interested to continue the project.

201. See Ripken, supra note 66, at 102-06 (explaining the legal, moral, organizational, psychological, sociological, theological, and political theories of the corporation as a person).

202. Id. at 105 . 
justice, but rather each "captures elements of truth." ${ }^{203}$ Ripken's insights ring true, and this limits the fruitfulness of ascertaining which conceptualizations support, versus those that do not support, corporate free speech rights.

A superior approach would be, therefore, to proceed differently. Instead of starting with one of the preexisting theoretical conceptualizations, I suggest we construct a conceptualization, from the ground up, that would justify the application of free speech rights. To the extent that a modern corporation can be accurately described by this newly constructed conceptualization, it ought, a fortiori, to receive the protections of the First Amendment as per Citizens United.

Fortunately, our undertaking need not start from scratch. For there already exists a theory of organizations and their proper role within a democratic republic. It is the theory of "associations" as espoused by Alexis de Tocqueville. ${ }^{204}$

\section{THE CORPORATION AS A TOCQUEvillian ASSOCIATION}

The political theory of Alexis de Tocqueville furnishes us with a means by which we can tether the free speech rights of the corporation with the corporation's theoretical conceptualization. This Section shows how, by drawing upon our tradition of conceptualizing the corporation differently depending upon historical realities and factual circumstances, we can conceive of some corporations today as "Tocquevillian Associations." Such corporations-and only such corporations-are fully deserving of the free speech rights afforded to them by the Supreme Court in Citizens United. ${ }^{205}$

\section{A. Relevance of Tocqueville}

Alexis de Tocqueville was a nineteenth-century French political theorist gifted with "a genius of perception."206 Fascinated with the apparent success of the United States, during an era when Europe was struggling with concepts of democracy, Tocqueville embarked upon a yearlong examination of America firsthand in 1831.207

\section{Id. at 102 .} (1835).

204. Alexis de TocQueville, Democracy IN America 3 (Henry Reeve trans., Bantam Books 2000)

205. Although American courts have clearly and repeatedly recognized the rights of associations (be they incorporated or unincorporated), this recognition has been undertheorized to say the least. E.g., Haitian Refugee Ctr. v. Civiletti, 503 F. Supp. 422, 474 (S.D. Fla. 1980) (recognizing organization's First Amendment rights), modified on other grounds, 676 F.2d 1023 (11th Cir. 1980). Moreover, in many instances, courts have recognized (either implicitly or explicitly) an association's assertion of such rights as simply a convenient means by which the rights of the association's members may be recognized. See NAACP v. Alabama, 357 U.S. 449,459 (1958) ("The association ... is but the medium through which its individual members seek to make more effective the expression of their own views."). This Article does not attempt to justify the recognition of associational rights in general, but rather uses Tocqueville's theory and insights to justify such recognition under certain circumstances. In short, this Article represents a modest contribution to the effort to "make some pre-legal cognitive peace with the phenomenon of the organization" as to enable an intelligible consideration of "the question of its appropriate normative treatment." MEIR DAN-COHEN, RIGHTS, PERSONS, AND ORganizations: A Legal THEORY FOR BuREAUCRATIC SOCIETY 27 (1986).

206. Joseph Epstein, Introduction to TOCQUEViLLE, supra note 204, at xix.

207. See id. at xxvi-xxxii (describing Tocqueville's joumey to America and the development of his book). 
He met and mingled with Americans both high and low, and from these labors produced his masterful, two-volume treatise: Democracy in America. ${ }^{208}$ His work received near universal acclaim and has been widely heralded "for different reasons by different generations" since. ${ }^{209}$ In it, he attempted to understand the grand interplay of human nature and self-government. 210 "Tocqueville has come to be viewed as the political scientist par excellence, and sometimes, more grandly, as a political philosopher, where he has often been ranked just behind Aristotle and Machiavelli as a political thinker."211

Tocqueville's observations and thought have had a profound effect on the subject of his study: America. ${ }^{212}$ In the legal field alone, the U.S. Supreme Court has cited to Tocqueville thirty-five times; lower federal and state court citations number in the hundreds. ${ }^{213}$ And this is not the product of some bygone era, for these citations continue to this very day, ${ }^{214}$ and Tocqueville remains "a fixture in contemporary American political discourse."215 In short, although the merits of Tocqueville's thoughts are certainly open to debate, their relevance cannot be denied..$^{216}$

\section{B. Tocqueville's Theory of Associations}

In Chapter 12 to Volume I of Democracy in America, Tocqueville introduces the subject of associations. ${ }^{217} \mathrm{He}$ acknowledges a variety of reasons why associations are formed, including the promotion of "public order, commerce, industry, morality, and religion." $218 \mathrm{He}$ adds that this variety results from the fact that "there is no end which the human will, seconded by the collective exertion of individuals, despairs of attaining."219

In his study in this section, Tocqueville confines himself to associations of "the political world." ${ }^{220}$ This is apparent in his definition of association, which immediately

208. Id. at $\mathrm{xxix}-\mathrm{xxxi}$.

209. Id. at xxvii, $\mathrm{xxxiii}$.

210. See id. at xxxvii (explaining the intersection of political and sociological elements in Tocqueville's work).

211. Id. at xxxvi.

212. Id. at xlii.

213. See, e.g., Hein v. Freedom from Religion Found., Inc., 551 U.S. 587 (2007) (referring to Tocqueville's observations of the United States judicial system under Article III); Van Orden v. Perry, 545 U.S. 677, 698 (2005) (Breyer, J., concurring) (quoting Tocqueville's observations regarding freedom of religion in the United States). A search of LexisNexis or Westlaw databases of the federal courts for Alexis de Tocqueville will return numerous results.

214. E.g., Libertarian Party of N.C. v. State, 707 S.E.2d 199, 208 (N.C. 2011).

215. Sheldon S. Wolin, Tocqueville Between Two Worlds: The Making of a Political and THEORETICAL LIFE 3 (2001).

216. But see John D. Inazu, The Strange Origins of the Constitutional Right of Association, 77 TENN. L. REV. 485, 549-56 (2010) (discussing the inapplicability of Tocquevillian thought to twentieth-century America).

217. TOCQUEVILLE, supra note 204 , at 218.

218. Id. at 219 .

219. Id.

220. Id. 
follows: "An association consists simply in the public assent which a number of individuals give to certain doctrines, and in the engagement which they contract to promote the spread of those doctrines by their exertions."221 By simply replacing the term "doctrines" with the term "undertakings," we have a broader definition that could be used to cover all associations, and not just political ones. Since Tocqueville addresses nonpolitical associations in Volume II, ${ }^{222}$ including, explicitly, commercial associations, this revised definition is a justifiable one.

For much of Chapter 12, Tocqueville discusses the distinction between associations that threaten society (as he sees in Europe) and associations that do not threaten society (as he sees in America). ${ }^{223}$ This difference lies chiefly in the wider ideological gulfs that mark European society, along with the militant nature of European associations during Tocqueville's time. ${ }^{24}$ As such, this portion of Tocqueville's remarks is largely inapplicable to the subject of this Article.

What is relevant in Chapter 12, for our purposes, is Tocqueville's justification of associations. As will become quickly apparent, Tocqueville values associations for important instrumental reasons. But he gives pride of place to reasons that are intrinsic, calling the right to associate a "natural privilege of man."225 Although he offers this opinion within the context of his discussion of political associations, neither the language nor logic of his expression suggests that it should be so limited:

The most natural privilege of man, next to the right of acting for himself, is that of combining his exertions with those of his fellow-creatures, and of acting in common with them. I am therefore led to conclude that the right of association is almost as inalienable as the right of personal liberty. No legislator can attack it without impairing the very foundations of society. ${ }^{226}$

In Chapters 5, 6, and 7 of the Second Book of Volume II, ${ }^{227}$ Tocqueville expounds upon associations more generally, addressing those "formed in the civil life, without reference to political objects." 228 Here he explicitly acknowledges (and includes) among these associations "commercial and manufacturing companies, in which all take part."229 Thus, it is clear that business enterprises are covered in Tocqueville's analysis to follow.

Tocqueville was struck by America's rich associational life. Although political associations were manifold, Tocqueville contextualizes them by noting that they are but "a single feature in the midst of the immense assemblage of associations" in the United States. ${ }^{230}$ As he puts it, "Americans of all ages, all conditions, and all dispositions,

221. Id.

222. See id. at 630-45 (discussing the role of public associations, their relationship to newspapers, and their ties to civil associations).

223. See id. at 225-27.

224. Id.

225. Id. at 224 .

226. Id.

227. Volume I is contained in one book; Volume II is organized into four books.

228. TOCQUEVILLE, supra note 204, at 630.

229. $I d$.

230. Id. 
constantly form associations."231

Tocqueville immediately contrasts the American situation with that of the European. In Europe at the time, almost every major undertaking was headed by the government, or a "man of rank." 232 In America, by contrast, associations were often at the helm of such ventures. ${ }^{233}$ Tocqueville opined that this was due to the lack of an aristocracy or powerful government in America, necessitating the use of associations to get things done. ${ }^{234}$ Individual Americans were, generally speaking, "independent and feeble," whereas each European aristocrat "constitute[d] the head of a permanent and compulsory association, composed of all those who are dependent upon him, or whom he makes subservient to the execution of his designs."235

Although Americans may not be as powerless, and European aristocrats as powerful, now as they were in 1831 , Tocqueville makes an important point of lasting relevance. In almost any society, the rich and powerful enjoy the advantages of association, as their extended network of patronage assures them a ready and willing pool of supporters. This is so regardless of whether the society fosters associational freedoms. The poor and the powerless, however, are oftentimes bereft of such advantages. To replicate them, these individuals need the ability to join together and form associations of their own. In a society where such ability is lacking even an otherwise democratic society-the unprivileged generally lack the ability to advance their interests or fend for themselves. Indeed, it was this very democratic and egalitarian impulse that led-in part-to the promulgation of statutes of general incorporation. ${ }^{236}$ The corporation in America was seen-at the time of Tocqueville-as "a means to equalize otherwise unbalanced competing economic forces." 237

With regard to government and its expansion, the ascendency of the corporation (and associations in general) provided an important check. For as some of Tocqueville's contemporaries recognized, "the more enfeebled and incompetent the citizens become, the more able and active the government ought to be rendered, in order that society at large may execute what individuals can no longer accomplish."238 Given the increasing complexity of modern society, and the fact that individuals are "less and less able to produce, of [themselves] alone, the commonest necessaries of life," Tocqueville foresaw that "the governing power will therefore perpetually increase, and its every efforts will extend it every day."239 And this cycle, once begun, is self-perpetuating, for the "more [government] stands in the place of associations, the

231. Id.

232. Id. at $630-31$.

233. Id.

234. Id. at 631-32.

235. Id. at 631 .

236. See Martin H. Redish \& Howard M. Wasserman, What's Good for General Motors: Corporate Speech and the Theory of Free Expression, 66 GEO. WASH. L. REV. 235, 246 (1998) (discussing the impact of corporate activity on society as a whole). See supra notes $95-97$ and accompanying text for a discussion of the development of statutes of incorporation.

237. Redish \& Wasserman, supra note 236, at 252 (summarizing Tocqueville's thoughts about the common purposes of associations).

238. TOCQUEVILLE, supra note 204, at 632 .

239. Id. 
more will individuals, losing the notion of combining together, require its assistance." ${ }^{240}$ Over the course of the twentieth century, economist and philosopher Wilhelm Ropke saw this play out, observing that one of the critical "counterweights against the accumulation" of state power was "private enterprise."241 If we look more closely, we can see that associations are able to serve as this important check on the state for at least two reasons.

First, by enabling individuals to accomplish what they could not otherwise accomplish alone, private associations limit the growth of the state. Private initiative, effectuated via association, obviates, to a degree, the need for an expanding state. ${ }^{242}$ This helps preserve an extended sphere of freedom for the individual-a sphere free of state dominance. ${ }^{243}$

Second, associations can serve as an effective bulwark against state power. ${ }^{244}$ Although an individual might not be able to take on city hall, an association of individuals certainly can. ${ }^{245}$ As Frances Hill put it: "Without effective organizations, individuals are left to confront government authority alone as isolated and atomized individuals." 246 The Supreme Court itself has observed the "critical role" played by associations as "critical buffers between the individual and the power of the State."247 Indeed, Tocqueville saw France's despotism after the French Revolution as largely "the result of the assertion that the only true civic relation was that of the individual and the State. ${ }^{248}$

240. Id. at 632-33. Cf. Timur Kuran, The Absence of the Corporation in Islamic Law: Origins and Persistence, 53 AM. J. COMP. L. 785, 789-93 (2005) (observing that the ascendency of the corporation historically accompanied the weakness of the state).

241. Wilhelm Rópke, a humane Economy: The Soclal Framework of the Free Market 145 (Elizabeth Henderson trans., 3d ed. 1998). An important qualifier to this statement would be Ropke's concern with offensive and unhealthy pluralism, whereby groups, including large business corporations, seek to use the government to do their bidding at the expense of others. Id. at 144-45.

242. See TOCQUEVILLE, supra note 204, at 623-33 (discussing how citizens can band together through associations in order to accomplish more than individually). This is consistent with modern ideas of civil society, which "stress the public yet non-governmental character of civil society" as a "realm of social life characterized by 'plural and particularistic identities.' James Fox, Fourteenth Amendment Citizenship and the Reconstruction-Era Black Public Sphere, 42 AKRON L. REV. 1245, 1249 (2009) (quoting Nancy L. Rosenblum \& Robert C. Post, Introduction to CIVIL SOCIETY AND Government 1, 3 (Nancy L. Rosenblum \& Robert C. Post eds., 2002)).

243. See Seymour Drescher, Dilemmas of Democracy 46 (1968) (discussing the relationship between associations and self-government in warding off state power).

244. See WoLIN, supra note 215 , at 235 (explaining how Tocqueville saw power controlled and influenced by an array of autonomous institutions).

245. Cf. Liam Seamus O'Melinn, The Sanctity of Association: The Corporation and Individualism in American Law, 37 SAN DIEGO L. REV. 101, 165 (2000) ("When faced with the individual who neither belongs to an approved [privileged] group nor has property to devote to a cause, American law has long given the same answer: Go and associate with others so as to become a bigger person, a corporate person.").

246. Hill, supra note 185, at 288. See also Richard Brooks, Law and Civil Society in the United States, Canada, Quebec, and the First Nations, 15 ARIZ. J. INT'L \& COMP. L. 1, 12-15 (1998) (arguing that "a tier of institutions, midway between the individual and centralized government, is an important part of any civil society").

247. Roberts v. United States Jaycees, 468 U.S. 609, 618-19 (1984).

248. O'Melinn, supra note 245 , at 143 . Arguably, under the ancien regime, this individual had a 
Associations also serve to temper the radical individualism that is so seared into the American character. ${ }^{249}$ For it is largely through associations that "[f]eelings and opinions are recruited, the heart is enlarged, and the human mind is developed."250 This, in turn, helps, in the words of one commentator on Tocqueville, to "generate a complex and beneficial network of social norms" indispensible to a free nation. ${ }^{251}$

Finally, Tocqueville discerns a connection between political associations and civil associations. Indeed, he sees a "natural, and perhaps a necessary" linkage between the two. ${ }^{252}$ As he explains:

Certain men happen to have a common interest in some concern-either a commercial undertaking is to be managed, or some speculation in manufactures to be tried; they meet, they combine, and thus by degrees they become familiar with the principle of association. The greater is the multiplicity of small affairs, the more do men, even without knowing it, acquire facility in prosecuting great undertakings in common. Civil associations, therefore, facilitate political association ... 253

To Tocqueville, civil associations provide a training ground for participation in public associations-and vice versa. ${ }^{254}$

Not surprisingly, Tocqueville counsels against taking action adverse to associations--even mere "civil associations." 255 For

[w] hen some kinds of associations are prohibited and others allowed, it is difficult to distinguish the former from the latter, beforehand. In this state of doubt men abstain from them altogether, and a sort of public opinion passes current which tends to cause any association whatsoever to be regarded as a bold and almost an illicit enterprise. ${ }^{256}$

Most relevant to our purposes, Tocqueville adds to his admonishment:

It is therefore chimerical to suppose that the spirit of association, when it is repressed on some one point, will nevertheless display the same vigor on all others; and that if men be allowed to prosecute certain undertakings in common, that is quite enough for them eagerly to set about them. When the

modicum of protection from the crown, in the form of a powerful mediating aristocracy and clergy. When such badges of privilege are wiped away (as in post-Revolutionary France and in the United States), and society is more equalized, there are fewer countervailing voices checking the state. See Redish \& Wasserman, supra note 236, at 251 (explaining the benefits corporate expression could have on its recipients).

249. See O'Melinn, supra note 245, at 102-05 (introducing the argument that the American legal system has traditionally protected groups as well as individuals).

250. TOCQUEVILLE, supra note 204, at 633 .

251. John O. McGinnis, Reviving Tocqueville's America: The Rehnquist Court's Jurisprudence of Social Discovery, 90 CALIF. L. REV. 485, 529 (2002) (explaining that associations help regulate social norms and individuals' behavior without intervention from the state). Others have commented upon the importance of associational life as well. E.g., Timothy L. Fort, The First Man and the Company Man: The Common Good, Transcendence, and Mediating Institutions, 36 AM. BUS. L.J. 391, 406 (1999). But see id. at 427 (discussing the antipathy of Hobbes and Rousseau toward traditional associations as inhibitive of freedom and equality).

252. TOCQUEVILLE, supra note 204 , at 640 .

253. Id.

254. $I d$.

255. See id. at 642 .

256. Id. 
members of a community are allowed and accustomed to combine for all purposes, they will combine as readily for the lesser as for the more importance ones; but if they are only allowed to combine for small affairs, they will be neither inclined nor able to effect it. ${ }^{257}$

In other words, the associational freedoms and the robustness of associational life are interrelated. Curtailment of association rights, even to a limited degree, risks ripple effects chilling associational activity in general. ${ }^{258}$

In sum, Tocqueville believed that associations were a "central and constitutive" element of American democracy. ${ }^{259}$ Moreover, as between civil and political associations, "Tocqueville actually believed that civil associations provided a greater benefit to a democratic society than political ones because they created civic energy without generating the factional strife of political associations." $260 \mathrm{He}$ cautioned that "[g]overnment should not be permitted to supervise or manage civil associations lest their independent influence on society be diluted."261

\section{Characteristics of a Tocquevillian Corporate Association}

Having set forth a summary of Tocqueville's theory of association, the remaining task before us is to decide how to apply that theory to modern corporate enterprises. For although Tocqueville explicitly included commercial associations in his analysis, he certainly "was not writing about organizations controlled by unaccountable managers and self-perpetuating boards." 262 What is needed, therefore, is an identification of those characteristics essential to the Tocquevillian Association, so as to enable us to determine which corporations ought to be categorized as such. Turning on this categorization is the advisability and justifiability of corporate political speech rights.

Perhaps the most important Tocquevillian insight (and a seemingly counterintuitive one) is the irrelevance of an association's actual purpose to the analysis. For Tocqueville observes that associations are created for a myriad of purposes, and in his recognition of genuine associations he does not discriminate among these purposes: "[Americans] have not only commercial and manufacturing companies . . . but associations of a thousand other kinds-religious, moral, serious, futile, extensive, or restricted, enormous or diminutive."263

This suggests that the purpose of an association ought not be a factor in

257. Id. at 643 .

258. This was the thrust of an op-ed jointly authored by the unusual bedfellows Greg Lebedev (chairman of the Center for International Private Enterprise, an affiliate of the U.S. Chamber of Commerce) and John Sweeney (chairman of the Solidarity Center, affiliate with the AFL-CIO). See Greg Lebedev \& John Sweeney, Op-Ed, On Free Association, Business and Labor Agree, WALL ST. J., Sept. 17, 2010, at A19 (arguing that strengthening freedom of association advances economic prosperity, stability, and democratic values)

259. McGinnis, supra note 251 , at 533.

260. Id. at 534. This would include Madison's fear of political associations as "factions." See Inazu, supra note 216, at 548-49 (explaining Tocqueville's belief, contrasted with Madison's, that associations would not threaten governmental stability in America).

261. McGinnis, supra note 251 , at 534 .

262. Hill, supra note 185 , at 289.

263. TOCQUEVILLE, supra note 204 , at 630 . 
determining its rights. To assert this irrelevance conflicts with a long established divide between commercial and noncommercial activity, between profit and nonprofit corporations. ${ }^{264}$ Both the Supreme Court, and commentators, have made this distinction. ${ }^{265}$ Within the context of First Amendment jurisprudence, this distinction is often linked to the "antidistortion" rationale for limiting the speech of corporations. ${ }^{266}$

This rationale supports the restriction of corporate speech on the basis of the "distorting effects of immense aggregations of wealth that are accumulated with the help of the corporate form and that have little or no correlation to the public's support for the corporation's political ideas." 267 This rationale, however, and the broader distinction between profit and nonprofit corporations, is premised upon two questionable presuppositions.

The first presupposition is that commercial or for-profit associations (which are ordinarily treated together) are wealthier than noncommercial or nonprofit associations (which are also ordinarily treated together). This presupposition simply does not hold true universally. Although commercial and for-profit enterprises may have more resources than noncommercial and nonprofit enterprises as a general matter, the entire thrust of this Article has been to move away from generalities. When one gets specific, there are certainly nonprofit institutions (such as Harvard University, for example) that dwarf the vast majority of for-profit commercial enterprises in terms of wealth and resources. ${ }^{268}$ And as a legal matter, there is nothing restricting the profitability or wealth of nonprofit institutions vis-à-vis for-profit businesses. ${ }^{269}$ Indeed, the very nomenclature of profit versus nonprofit is misleading, as both types of organizations generally seek and obtain profitability. ${ }^{270}$ The critical difference is that the profits of a for-profit enterprise are distributed to others, whereas the profits of a nonprofit are put back into the enterprise. ${ }^{271}$

Moreover, to the extent that commercial/for-profit corporations enjoy an advantage in terms of wealth and power, this suggests that they are excellent candidates

264. See Michael C. Dorf, The Good Society, Commerce, and the Rehnquist Court, 69 FORDHAM L. REV. 2161, 2163-64 (2001) (distinguishing the legal treatment of commercial and noncommercial activities).

265. See, e.g., Roberts v. United States Jaycees, 468 U.S. 609, 620 (1984) (theorizing that along the spectrum of corporations "lies a broad range of human relationships that may make greater or lesser claims to constitutional protection"); Usha Rodrigues, Entity and Identity, 60 EMORY L.J. 1257, 1259-64 (2011) (discussing the blurred boundary between the for-profit and nonprofit sectors).

266. See, e.g., Austin v. Mich. Chamber of Comm., 494 U.S. 652, 659-61 (1990) (recognizing the governmental interest in preventing corporate influence in the political process).

267. Id. at 660 .

268. Cf. Jeff Trexler, Design Jurisprudence and the Nonprofit Style, 14 YALE J.L. \& HuMAN. 321, 38283 (2002) (describing the ability of nonprofit organizations, including schools, to exploit their nonprofit categorization)

269. Hansmann, supra note 144, at 501.

270. See Henry B. Hansmann, The Role of Nonprofit Enterprise, 89 YALE L.J. 835, 838 (1980) (stating that many nonprofits turn annual profits).

271. Hansmann, supra note 144 , at 501 . But even this can be misleading, as the line between the distribution of profits, and the payment of exorbitant salaries, can sometimes differ little conceptually. E.g., Robyn Blumner, Aiding the Poor Shouldn't Make you Rich, St. Petersburg TimeS, Apr. 19, 2009, at 5P; Stephanie Strom, Lawmakers, Tightening Belts, Question Nonprofit Salaries, N.Y. TIMES, July 27, 2010, at A 12. 
when it comes to serving as a check on government-a critical role of the association in Tocquevillian thought. As Martin Redish and Howard Wasserman note, the ability to check government requires "power, resources, and incentive . . corporations generally possess all three."272 Thus, contrary to being a drawback, the wealth of for-profit corporations supports their identification as Tocquevillian Associations.

That said, to the extent that wealth is related to size, distinctions based on wealth are not entirely meritless from a Tocquevillian perspective. There is an argument, suggested by the literature on associational theory, that large institutions are less capable of serving as true associations, because the human brain has difficulty relating to groups (in the enriching matter that we would expect of a Tocquevillian Association) beyond a certain size. ${ }^{273}$ Although the "optimal size" of a group for such purposes is debatable, it appears to be "dramatically smaller than megastructures such as the nation-state or the global corporation." 274 This suggests that, although Tocqueville did not discriminate among associations when it came to questions of wealth, ceteribus paribus, larger corporations have less persuasive a claim to categorization as Tocquevillian Associations for reasons having to do with their size alone..$^{275}$

The second presupposition behind the for-profit and nonprofit distinction displays a more qualitative, and, for our purposes, more important concern. It has to do with the nature of the for-profit/commercial enterprise, versus the nature of the nonprofit/noncommercial enterprise. ${ }^{276}$ And this concern melds with another aspect of the association that can be distilled from Tocqueville's writings: the extent to which an association serves as a "mediating institution" (to apply a modern term to the phenomenon Tocqueville describes). ${ }^{277}$ Tocqueville believed that associations were essential because, among other things, they provided a vehicle through which "[f]eelings and opinions are recruited, the heart is enlarged, and the human mind is developed." 278 In short, associations provide individuals with community-an essential

272. Redish \& Wasserman, supra note 236, at 263. See also MICHAEL NOVAK, THE SPIRT OF DEMOCRATIC CAPITALISM 178 (1982) ("Without the large private corporation, there would be one fewer among the large private forces strong enough to check the growing ambitions of the administrative state.").

273. Fort, supra note 251 , at $428-29$ (arguing that evolutionary history makes small associations optimal). Similarly (and analogously), Thomas Donaldson pointed out that smaller corporations could generally claim moral agency more readily than larger corporations. THOMAS DONALDSON, CoRPORATIONS \& MORALITY 31, 110-11 (1982).

274. Fort, supra note 251 , at 429.

275. Exceptions would be possible to the extent that a large corporation is divided into smaller units. In such situations, the individual units may lay claim to associational status, although the parent corporation would not be so entitled. And beyond this, some very large corporations have apparently been able to generate genuine communities despite their size. See Don Mayer, Community, Business Ethics, and Global Capitalism, 38 AM. BUS. L.J. 215 (2001) (discussing the interplay between corporations and communities); Keith O'Brien, From Startup to Tech Titan, PR WEEK USA, Mar. 26, 2007, at 17-18 (discussing Google's efforts to create a unique corporate culture in the midst of exponential growth).

276. See Rodrigues, supra note 265 , at 1291-92 (discussing how the nondistribution constraint creates a unique social identity and trust among participants of nonprofits).

277. See Fort, supra note 251 , at 430 (describing how mediating institutions provide a framework with which members may shape their identities).

278. TOCQUEVILLE, supra note 204, at 633 . 
component of human flourishing. ${ }^{279}$ As mediating institutions, associations serve the manifold purposes of socialization, self-realization, and the inculcation of civic republicanism. ${ }^{280}$

In their examination of corporations, many commentators conclude that only nonprofits embody this communitarian dimension. Drawing upon social identity theory, Usha Rodrigues persuasively argues that "[n]onprofits can create a social identity in association, which for-profit corporations cannot." 281 This is because of the inability of nonprofits to distribute profits, and the distinctiveness of a nonprofit's "values and practices in relation to ... comparable groups." 282 This helps nonprofits carve out a distinctive kind of identity, from which those associated with it derive a certain prestige and "psychic income."283

Rodrigues recognizes that certain philanthropic for-profit corporations have blurred the distinction between profit and nonprofit corporations (she identifies, specifically, Starbucks and Whole Foods), yet maintains that the distinction persists. ${ }^{284}$ It is here that I part company with Rodrigues, for I believe that there is a point at which we might have a technical distinction but not a substantive difference. For many of Rodrigues's very own arguments in support of nonprofit identity can and do apply to certain for-profit companies as well. Rodrigues is unwilling to follow her own cogent reasoning to its logical conclusion, and draws, I suggest, an unnecessary line in the sand.

Mark Hager, similarly, argues in favor of a robust protection of associations and their rights-yet would exclude from this protection for-profit business corporations. ${ }^{285}$ He justifies this exclusion primarily due to his assertion that "[a] business corporation is not essentially a collection of people, but rather, essentially a collection of capital."286 Hager recognizes the debatability of this assertion, and quickly works to counter those who would attack it as "excessively simplistic." 287 In doing so, he argues that "[t]he common bond among stockholders lies almost exclusively in their mutual hope of profits" whereas the membership of other (nonprofit) associations is "typically held together by a broader and more complex range of social interests and purposes: political, educational, charitable, and fraternal, as well as economic."288

Hager's critique of the corporation as a profit-obsessed automaton is a common one. As Dan Greenwood puts it, the corporation is, by law, beholden to "the interests of

279. See Fort, supra note 251, at 406 (arguing that organizations provide a place for the individual to learn that one's self is dependent upon associations with others); McGinnis, supra note 251, at 529 (describing Tocqueville's view that free association fosters creation of diverse and useful networks of social norms).

280. Fort, supra note 251 , at $405-06,430$.

281. Rodrigues, supra note 265 , at 1320 .

282. Id. at 1282 (quoting Blake E. Ashforth \& Fred Mael, Social Identity and the Organization, ACAD. MGMT. REV. 20, 24-25 (1989)).

283. Id. at 1284 .

284. Id. at 1259.

285. Mark M. Hager, Bodies Politic: The Progressive History of Organizational "Real Entity" Theory, 50 U. PITT. L. REv. 575, 648-50 (1989).

286. Id. at 650 .

287. Id. at $650-51$.

288. Id. at 651 . 
a fictional creature called a shareholder that has no associations, economic incentives or political views other than a desire to profit from its connection with this particular corporation." 289 This ties in with Rodrigues's view that the presence of shareholders constitutes an important distinguishing feature separating for-profit corporations from nonprofit corporations. ${ }^{290}$

Again, as a matter of general supposition, I challenge neither Greenwood nor Hager's description. ${ }^{291}$ I agree with Hager's assertion that nonprofit organizations "display a rich and various associational and 'political' character rarely displayed among stockholders in a corporation." ${ }^{292}$ That said, I seize upon Hager's use of the qualifier "rarely." "Rarely" connotes that some corporations do indeed share in these traits, hence my assertion that some corporations are deserving of First Amendment protections. ${ }^{293}$ The world of commercial/for-profit corporations is a heterogeneous one, and we should be open to the fact that some of these enterprises will bear all the significant hallmarks of a Tocquevillian Association. ${ }^{294}$ Indeed, in the years since both Hager and Greenwood's articles were written, some states have adopted benefit corporation statutes, explicitly authorizing corporate boards to prioritize other objectives-social objectives with a view toward the common good-over shareholder profits. ${ }^{295}$ And well before that, several states adopted corporate constituency statutes, which allow managers to take into account the interests of nonshareholder stakeholders (including employees) when making decisions."296 Thus, although Hager and

289. Daniel J.H. Greenwood, Essential Speech: Why Corporate Speech Is Not Free, 83 IOWA L. REV. 995, 1033 (1998).

290. See Rodrigues, supra note 265, at 1267 (finding that the absence of shareholders for nonprofits results in a lack of individuals within the organization who are incentivized to monitor the actions of managers).

291. Although, as I and others have argued, the law does not necessarily compel a corporation to maximize shareholder profits. E.g., BAINBRIDGE, supra note 14, at 408-10; Colombo, supra note 49, at 281; Redish \& Wasserman, supra note 236, at 237.

292. Hager, supra note 285 , at 651 .

293. Hager also makes the argument that for-profit associations are less deserving of First Amendment rights due to the fact that they are not governed by the "one person, one vote" paradigm, but rather by the "one share, one vote." Id. at 652 . This calls to mind the "fervor for democracy" that, during the Revolutionary Era, "led some states to recognize the rights of churches only if they follow democratic internal decision making processes." Evelyn Brody, Entrance, Voice, and Exit: The Constitutional Bounds of the Right of Association, 35 U.C. Davis L. REv. 821, 862 (2002). In short, it strikes me as Orwellian to deny people the right to organize in the manner they see fit in the name of democracy and freedom.

294. Cf. Graver, supra note 153, at 248-49 (recognizing critical differences among commercial corporations, such that some ought to possess free speech rights while others should not).

295. See Max Abelson, The New Be Good Business: Albany Gives Birth to New York's Benefit Corporation, N.Y. OBSERVER, (June 23, 2010, 12:56 AM), http://www.observer.com/2010/06/the-new-begood-business-albany-gives-birth-to-new-yorks-benefit-corporation (describing New York's consideration of creating benefit corporations). See supra note 147 for a list of states with "benefit corporation" statutes. Some have suggested that the proliferation of such corporations is vitally needed. See Michael Troilo, Caritas in Veritate, Hybrid Firms, and Institutional Arrangements, 14 J. MARKETS \& MORALITY 23, 25-26 (2011) (discussing Pope Benedict XVI's assertion that society needs to "create space in the market for actors who 'operate according to principles other than those of pure profit, without sacrificing the production of economic value in the process"' (quoting POPE BENEDICT XVI, ChARITY IN TRUSTH: CARITAS IN VerITATE 37 (2009))).

296. Barbara J. Fick, The Changing Face of the American Workplace, 12 NOTRE DAME J.L. ETHICS \& PUB. POL'Y 1,7 (1998). 
Greenwood accurately describe the prevailing understanding of the corporation during our times (and, perhaps, the prevailing nature of most corporations as well) their description does not accurately describe each and every corporation.

Many corporations simply do not view themselves as the profit-maximizing machines suggested above. As Lisa Fairfax has documented, companies increasingly distance themselves from profit maximization, and instead stress their balanced commitment to a variety of corporate stakeholders. ${ }^{297}$ This, in turn, may have important normative and behavioral effects. ${ }^{298}$

Whole Foods, for example, is simply not wedded to shareholder profit maximization. Its CEO, John Mackey, explicitly disavows the profit maximization objective. ${ }^{299} \mathrm{He}$ acknowledges that this may very well be the objective of the company's investors, but adds that it is not the objective of its other stakeholders. ${ }^{300}$ Under his leadership, Whole Foods strives to provide value to all its constituencies. ${ }^{301}$ As for its shareholders, he bluntly puts it this way, "we 'hired' our original investors. They didn't hire us." 302

The ability of a for-profit corporation to have an authentic "identity" is further attested to by the scores of employees, investors, and customers who are often drawn to a particular corporation because of its unique qualities. ${ }^{303}$ Corporations have real and distinct cultures-even values. ${ }^{304}$ As such, they enable people to "self-realize by

297. Lisa M. Fairfax, The Rhetoric of Corporate Law: The Impact of Stakeholder Rhetoric on Corporate Norms, 31 J. CORP. L. 675, 676-78 (2006).

298. Id.

299. Rethinking the Social Responsibility of Business, REASON, Oct. 2005, at 29, 29-30.

300. Id. at 30 .

301. Id.

302. Id. at 31 .

303. See Shiela M.J. Bonini, et al., The Trust Gap Between Consumers and Corporations, 2007 MCKINSEY Q. 6, 7-8 (finding that consumers "expect large companies to address sociopolitical problems, such as climate change and the affordability of drugs in developing countries"); Redish \& Wasserman, supra note 236, at 254 (arguing that associating with corporations provides a venue for self-realization); 2007 CONE CAuse Evolution \& ENVIRONMENT SURVEY, CONE COMM. 3 (2007), available at http://www.coneinc.com/files/2007ConeSurveyReport.pdf (revealing that "over time, Americans have become more likely to consider a company's reputation when making purchase, employment, and investment decisions."); IMPACT INVESTMENTS: AN EMERGING ASSET CLASS, J.P. MORGAN 5 (2010) (finding that impact investment offers a new alternative for funneling large sums of private capital into social endeavors); Lawrence Glickman \& Steven E. Livingston, Whole Foods Boycott: The Long View, WASH. Post (Sept. 2, 2009, 5:30 AM) http://voices.washingtonpost.com/shortstack $/ 2009 / 09 /$ whole_foods_boycott_the _long_v.html?hpid=news-col-blog (describing how boycotts are used by consumers to force companies to be more socially and environmentally responsible); Nicholas Timmons, Impact Investment "A Burgeoning Asset Class", FN. TIMES (Nov. 28, 2010, 6:02 PM), http://www.ft.com/intl/cms/s/e875dda6-fae6-11df-b57600144 feab49a (stating that impact investment allows investors to have a positive social impact); Raphael Bemporad, How Conscious Consumers Are Redefining Value in a New Economy, CASE FouNd. (Apr. 23, 2009), http://www.casefoundation.org/blog/how-conscious-consumers-are-redefining-value-new-economy8701 (stating that a significant amount of consumers make choices about which products to buy based on the social and environmental reputations of companies); Benefits of Becoming a Sustainable Business, EcoOFFICIENCY.COM, http://www.eco-officiency.com/benefits_becoming_sustainable _business.html (last visited Oct. 28, 2012) (finding that consumers are more attracted to companies who are socially and environmentally conscious).

304. See Redish \& Wasserman, supra note 236, at 237 (emphasizing that corporations are not merely 
engaging and investing in business and by participating in and personally benefitting from the political-economic system through the power of collective action." 305

And as organizational scholars have pointed out, different corporations have "distinctive cultures." ${ }^{306}$ Indeed, not even all large, for-profit business corporations can justifiably be lumped together as essentially identical. "It is not true that all big companies are the same--they aren't .... Companies develop their own distinctive personality and ethos which is so ingrained, so much a part of them, that the corporate identity expresses itself in their every action." 307

A variation of the identity-based line of distinction between profits and nonprofits argues that the message conveyed by associating with a for-profit versus a nonprofit organization differs substantially. The Supreme Court captured this distinction well in Federal Election Commission v. Massachusetts Citizens for Life, Inc., ${ }^{308}$ where it explained that "[i]ndividuals who contribute to [a politically-oriented nonprofit] are fully aware of its political purposes, and in fact contribute precisely because they support those purposes." 309 The Court expressly contrasted this with the for-profit world, where an individual's investment or employment decision was characterized only as "for economic gain." 310 This theme recurs in the Supreme Court's "expressive association" jurisprudence, most famously in Justice O'Connor's concurrence in Roberts $v$. United States Jaycees, where she explicitly excludes those organizations that are predominantly "commercial" from the expressive association categorization. ${ }^{311}$

Such a view is, again, overly simplistic. As Evelyn Brody points out, "[m]any organizations" (be they profit or nonprofit) "have multiple purposes," and as such individuals belong to them for a variety of reasons. ${ }^{312}$ To this, John McGinnis adds that

"faceless, robotic profit maximizers," but rather perform an "important democratic function in facilitating the personal self-realization" of stakeholders).

305. Id. at 254. See also Stephen F. Copp, A Theology of Incorporation with Limited Liability, $14 \mathrm{~J}$. MARKETS \& MORALITY 35, 41 (2011) ("The idea of human flourishing is often more associated with voluntary associations . . . but should be extended to business.").

306. Bucy, supra note 11 , at 1123-27.

307. Id. at 1123 (quoting Wally Olins, The CORPORATE Personality 82 (1978)).

308. 479 U.S. 238 (1986).

309. Mass. Citizens for Life, 479 U.S. at $260-61$.

310. Id. at 260.

311. Roberts v. United States Jaycees, 468 U.S. 609, 634-35 (1984). The Supreme Court's "expressive association" jurisprudence serves to protect the autonomy of organizations that exist for the purpose of engaging in protected First Amendment expression. See Erica Goldberg, Amending Christian Legal Society v. Martinez: Protecting Expressive Association as an Independent Right in a Limited Public Forum, 16 TEX. J. C.L. \& C.R. 129, 133-34 (2011) (stating that the expressive association category "safeguards group members' ability to associate with each other in order to engage in protected expression"). An interesting question, and one which overlaps with the inquiry of this Article, is whether certain for-profit corporations should be entitled to recognition as expressive associations (notwithstanding Justice O'Connor's opinion). Randall P. Bezanson, Sheila A. Bentzem, and C. Michael Judd address this question in Mapping the Forms of Expressive Association, 40 PEPP. L. Rev. (forthcoming Dec. 2012). They conclude that "in the modern business corporation the associational claim should not be recognized at all." Id. at 25 . For the reasons substantially similar to those set forth in this Article, I disagree with their conclusion, and believe that whether or not a particular business corporation qualifies as an expressive association ought to be decided upon a case-by-case basis, and not subject to a blanket prohibition.

312. Brody, supra note 293, at 863-64. 
"[a]s society becomes wealthier, the distinction between what many people do for a living and what they do to express themselves blurs." 313 The decision to invest in, work for, or patronize a given business corporation may be (for some individuals) as political as it is economic. ${ }^{314}$ Significantly, in an age when people are working longer hours than ever before, when technology largely obliterates the distinction between on and off duty, ${ }^{315}$ when substantial leisure time is in shorter supply, mundane employment and consumer choices may very well be one of the few realistic and effective avenues that the individual has nowadays to express himself or herself. And although not every employee of a particular corporation may agree with all that corporation's political speech, not every donor to a political advocacy group necessarily agrees with everything the group advocates. ${ }^{316}$ Neither should undercut the entity's claim to an identity. ${ }^{317}$

Indeed, a substantial body of scholarship exists affirming the for-profit corporation's ability to serve as a genuine association. Timothy Fort, for example, laments the fact that the business corporation has been "neglected" as a mediating institution in society. ${ }^{318} \mathrm{He}$ lists five reasons why business corporations should act and be treated as mediating institutions:

First, if being in such an institution assists in moral formation and identity, then it simply is a good thing to do regardless of whether it is good business. Second, since so much of a person's waking hours are in business work, the corporation provides an opportunity to develop moral behavior. Third, some scholars have argued that business demands time from employees that once was available for traditional mediating institutions like the family, neighborhood, and voluntary organizations. One then could argue that an obligation in this "takeover" is the obligation to be a mediating institution. Fourth, a mediating institution which is primarily concerned with the development of its internal members might have a corporate analogue that is efficacious if internal "stakeholders" have priority in corporate social responsibility. Fifth, many businesses and business strategies depend upon a

313. McGinnis, supra note 251 , at $538 \mathrm{n} .268$.

314. As Justice Douglas remarked: "Joining is one method of expression." Lathrop v. Donohue, 367 U.S. 820, 882 (1961) (Douglas, J., dissenting).

315. Olivera Perkins, Smartphones Let You Take Work Anywhere . . That's a Problem: Mobility Blurs Lines Between Workplace, Home, CLEV. PLAIN DEALER, July 27, 2009, at A1.

316. See Redish \& Wasserman, supra note 236 , at 272-73.

317. Interestingly, perhaps Rodriguez and Hager's adulation of the nonprofit corporation leads them to support a free-speech regime that is actually overinclusive. Recent scholarship on the nature and govemance of nonprofits suggests that not all is wonderful in the land of the noncommercial enterprise. See Brody, supra note 293, at 859-61 (stating that the donor's voice can "uniquely trump all others"). The existence of powerful patrons, for example, can belie idealized notions of community and voice. See id. ("If the donor imposes a particular charitable purpose on a charitable trust, and the purpose fails, the courts may apply cy pres doctrine to reform the trust to as close a purpose as possible to the original"). As such, I do not believe that nonprofits should get a free pass when it comes to the First Amendment, but rather ought to be evaluated according to the same criteria used to evaluate for-profit corporations. That said, I find it unlikely that many nonprofits would fail to pass muster as deserving of free-speech rights under such an evaluation, but in principle I suggest that they ought to be subject to evaluation nonetheless.

318. Fort, supra note 251 , at 433-34. 
notion of a business that is acting very much like a mediating institution. ${ }^{319}$

$\mathrm{He}$ is not alone in this regard. "Business ethicists have suggested that corporations today can, and possibly must, serve as mediating institutions in society." 320 Indeed, " $[\mathrm{t}$ ] the extent that so many people spend most of their day working in or interacting with corporate organizations, 'the corporation represents a value-laden institution that outranks the local community as a focus of loyalty and a medium for selfrealization." 321 As Michael Novak explains:

The business corporation is ... a "mediating structure," that is, a social institution larger than the individuals who make it up, but smaller than the state. An institution both voluntary and private, it stands between the individual and the state and is, perhaps (after the family), the crucial institution of civil society. ${ }^{322}$

Novak has gone so far as to develop what can rightly be called a "theology of the corporation." 323 Building on Aristotle's observation that human beings are "social animals," who can only flourish in a community, ${ }^{324}$ Novak sees the modern business corporation as providing that community. ${ }^{325} \mathrm{He}$ calls the corporation "a magnificent social invention, prior in its existence to the modern nation-state," 326 the importance of which has increased given the growth of the state, ${ }^{327}$ and the decline of other mediating institutions. ${ }^{328}$ Indeed, the demands of work today are such that it is unrealistic to expect people to develop their character and personalities entirely outside the workplace. 329 "For many of us, the two most important institutions in our lives are our families and the organizations for which we work." 330 And for many if not most people, the workplace is a corporation. It certainly is true that not every corporation lives up to the lofty role that Fort and Novak define for it. But, with equal certainty, some do.

Finally, another mark of a Tocquevillian Association is that it is a combination of

319. Fort, supra note 251, at 434 (footnotes omitted).

320. Ripken, supra note 66, at 146 (citing Timothy L. Fort, Business as Mediating Institution, 6 BUS. ETHICs Q. 149, 151, 155-57 (1996)).

321. Id. at 146 (quoting Norton E. Long, The Corporations, Its Satellites, and the Local Community, in THE CORPORATION IN MODERN SOCIETY 202, 202 (Edward Mason ed., 1959)).

322. MiChAel NOVAK, THREE IN ONE 233 (Edward W. Younkins ed., 2001).

323. Michael Novak, TOWARd a Theology of the Corporation 33 (1990).

324. See ARISTOTLE, POLITICS 6 (Benjamin Jowett trans., 1999) (remarking that a "social instinct is implanted in all men by nature"); Richard J, Regan, Virtue, Religion, and Civic Culture, 13 MIDWEST STUD. PHILOS. 342, 343 (1988) (discussing Aristotle as one of a few ancient philosophers that rejected the idea that individualism is the "measure of all things" without regard to community).

325. See NovAK, supra note 322, at 23 (finding that various social organisms like business enterprises and corporations have supplemented familial loyalty).

326. Michael NOVAK, THE FUtURE OF THE CORPORATION 5 (1996).

327. NOVAK, supra note 272, at 178 (1982).

328. See Ripken, supra note 66, at 153 (describing the views of Stephen Long and Timothy Fort).

329. See id. ("Work consumes too much time for one to think that virtuous habits are only cultivated in some separate cultural sphere and then brought to the corporation." (quoting D. Stephen Long, Corporations and the Common Good, 4 AVE MARIA L. REV. 77, 98 (2006))).

330. Id. (quoting Michael Naughton, The Corporation as a Community of Work: Understanding the Firm Within the Catholic Social Tradition, 4 AVE MARIA L. REV. 33, 40-41 (2006)). 
"individuals." ${ }^{331}$ The natural right of association that Tocqueville recognizes lays in the fundamental human activity of "combining [one's] exertions with those of his fellowcreatures, and of acting in common with them." 332

As elementary as this particular characteristic may seem, it actually does serve to establish some important parameters. For there do exist many corporations that are merely paper entities. This would include, for example, certain holding companies, which serve as mere shells established for the sole purpose of evading or enjoying certain legal prescriptions, ${ }^{333}$ along with certain investment vehicles, which are little more than automated trading accounts. ${ }^{334}$ Such would not be associations under Tocqueville's theory, and therefore undeserving of First Amendment rights.

In sum, it would appear as though a Tocquevillian Association would be marked by (1) an assemblage of individuals, (2) a manageable size, and (3) a clear identity. The corporation's objectives, along with its profitability and wealth per se, should not factor into the determination. ${ }^{335}$ Corporations bearing these characteristics should be afforded the fullest level of First Amendment rights and protections recognized by Citizens United, for all the reasons identified by Tocqueville and others. ${ }^{336}$

Not coincidentally, these same characteristics are reminiscent of both the real entity and aggregation models of the corporation - each of which were found supportive of corporate free speech rights. ${ }^{337}$ And this is because under each of these conceptualizations we have an institution that is predominantly human (versus predominantly artificial). Under each conceptualization, the corporation is envisioned not as some state-created artifice, or some imaginary construct, but a genuine article created for the fulfillment of authentic collective human needs and aspirations-"a community of people voluntarily working together for common and/or compatible goals and having, in varying degrees, shared values and concerns." 338

331. See supra text accompanying note 221 for a definition of a Tocquevillian Association.

332. TOCQUEVILLE, supra note 204, at 224.

333. Dean Kalant, Who's In Charge Here?: Requiring More Transparency In Corporate America: Advancements In Beneficial Ownership For Privately Held Companies, 42 J. MARSHALL L. Rev. 1049, 1053 n. 19 (2009).

334. See Laurin Blumenthal Kleiman \& Carla G. Teodoro, Forming, Organizing and Operating a Mutual Fund-Legal and Practical Considerations, in THE ABCs OF MUTUAL FUNDS (PLI Corp. Law \& Practice Course, Handbook Series No. 18809, 2009), WL 1744 PLI/CORP 35 (explaining the example of mutual funds as remote trading accounts for investors); Jacob Preiserowicz, Note, The New Regulatory Regime for Hedge Funds: Has the SEC Gone Down the Wrong Path?, 11 FORDHAM J. CORP. \& FIN. L. 807-14 (2006) (describing the structure and nature of hedge funds); Mark J. Roe, A Political Theory of American Corporate Finance, 91 COLUM. L. REv. 10, 10-12 (1991) (reviewing the structure of financial investment and banking institutions).

335. See supra Part IV.C for a discussion of characteristics of a Tocquevillian Corporate Association.

336. This is analogous to the conclusion reached by Thomas Donaldson in his consideration of moral agency. Donaldson, supra note 273 , at 30 . He predicates the granting of corporate rights upon the existence of moral agency, and in so doing observed that due to their diversity, not all corporations would qualify as moral agents (and as such not all corporations should enjoy constitutional rights and protections). Id.

337. See supra Part IIl.A for discussion of the corporation being viewed as a rights-bearing person.

338. Younkins, supra note 67 , at $101-02$. 


\section{IMPLEMENTATION}

Arguably, identifying the characteristics of a Tocquevillian Association in order to categorize corporations into one theoretical camp or the other is the easy part. Far more difficult is to settle upon some mechanism by which this identification process can be undertaken in reality. In this brief section, I shall outline four potential ways in which this could be done:

The most ambitious approach would be for state legislatures to set forth parameters (keyed to the distinguishing characteristics of the Tocquevillian Corporate Association: individuals, size, and identity) that, if met, would enable an incorporated entity to robustly avail itself of the free speech rights enunciated in Citizens United. ${ }^{339}$ A corporation applying for such treatment would have to make a showing before an applicable state agency that it indeed falls within the necessary parameters, and the agency would grant or deny the application depending upon the strength of this showing. ${ }^{340}$ The most significant feature of the showing would be the existence of a genuine corporate identity and community-something more robust than the platitudes that mark virtually every business organization today. ${ }^{341}$ At a minimum, one would expect the corporation's values and commitments to be articulated, with a degree of detail, in the corporation's charter or articles of incorporation. The inclusion of such language would require shareholder approval-but the necessary showing should, ideally, also reflect buy-in from other corporate constituencies as well. An employee vote, and even some form of customer certification, would go a long way toward establishing the authenticity and credibility of a corporation's claims of association.

Alternatively, state corporate law could promulgate default rules that restrict corporate political spending absent an "opt-in" by the corporation. This opt-in could be via the traditional mechanism of a shareholder amendment to the corporate charterbut, as per the previous suggestion, it could, perhaps, also contain a requirement that the opt-in be approved by other members of the corporate community as well. Such an approach has the advantage of simplicity and clarity. It also removes the state from case-by-case decision making, a process that is subject to corruption and manipulation. ${ }^{342}$ It also permits corporations to define their own roles in the political process - an advantage or disadvantage depending upon one's perspective.

339. I have chosen my words carefully here, because it remains an open question (in my mind at least) whether state legislatures can completely undo Citizens United via revisions to their statutes of general incorporation. See supra note 8 for discussion of state government power to restrict the constitutional rights of corporations. That said, it would seem as though state legislatures could certainly chip away at the freedoms ushered in by Citizens United, at least at the margins, hence the relevancy of this particular suggestion. Id.

340. This is analogous to a solution proposed by Richard Brooks in his analysis of the nonprofit sector, and its ability to furnish society with mediating institutions. See Brooks, supra note 246 , at $30-34$. After surveying the diversity of nonprofits, Brooks concluded that "[p]erhaps what is needed is a more careful delineation of non-profits along the lines of the classification of mediating institutions according to principles. ... Each should then be treated differently depending upon its respective [classification]." Id. at 34.

341. Cf. Fairfax, supra note 297 , at 678 (explaining that the emergence of stakeholder rhetoric in opposition to the profit-maximization norm has an intrinsic value).

342. Indeed, one of the reasons that statutes of general incorporation supplanted the granting of corporate charters on a case-by-case basis was to avoid such very corruption. Morton J. Horwitz, Santa Clara Revisited: The Development of Corporate Theory, 88 W. VA. L. REV. 173, 181 (1985). 
Without state action, corporate political speech could be reined in via the passage of disabling amendments to corporate charters-amendments, brought by investors, stripping corporations of their rights to exercise free speech. ${ }^{343}$ Naturally, investors desirous of their corporation's participation in the political process would prescind from such amendments. ${ }^{344}$

Finally, and perhaps least likely and least advisable, courts could wade into this thicket. Courts could attempt to utilize the principles of Tocquevillian Associations set forth above to guide their interpretation of "speech" as per Citizens United as future cases arise.

\section{CONCLUSION}

Citizens United makes very good sense if limited to those corporations that are accurately described as Tocquevillian Associations. It makes poor sense if applied to corporations generally. As such, Citizens United is both a step forward and a step backward. Efforts to reverse or roll back Citizens United are laudable insofar as they are restricted to those corporations that do not qualify as Tocquevillian Associations.

Recognition of the Tocquevillian Corporate Association would admittedly complicate, rather than simplify, corporate jurisprudence And another layer of complexity to anything is rarely welcomed. But I advert, again, to Susanna Ripken, who wrote,

[w]e should adopt a more nuanced, multi-faceted, and perhaps 'messier' model of the corporation, and we should do so not with a sigh of resignation or defeat in that we could not compose a more neat and tidy theory . . . but with a satisfaction in knowing that the complex nature of corporations deserves no less. ${ }^{345}$

Lastly, it is important to bear in mind the fundamental purpose of this effort to justify corporate political speech on the part of certain corporations. It is not, ultimately, to bestow rights and privileges upon the corporation for the sake of the corporation per se, but rather for the sake of the individual persons who constitute the

343. Interestingly, data on corporate political speech tend to support this dichotomy. For it has been found that firms where "an entrepreneur or founding family" remains actively involved, whether privately held or publicly traded, "are more likely to contribute to independent political organizations in the first place, and once they do contribute, give a far greater amount relative to firms without a principal owner [present]." Susan Clark Muntean, Corporate Independent Spending in the Post-BCRA to Pre-Citizens United Era, 13 Bus. \& POL. 1, 1 (2011). I see the presence of such overpowering individuals as a rough marker of identity-evidence of an animating "vision" versus a sterile mission statement forged by someone long forgotten. With such identity would naturally come a greater willingness to engage the political process, and a lesser sense that it was anyway inappropriate.

344. There is evidence that American corporation management is already conforming its policies regarding political spending to the appetite of corporate shareholders. See Kenneth P. Doyle, Companies Seen Moving Toward Disclosure On Their Own After Citizens United Ruling, 80 U.S.L.W. 610 (Nov. 8, 2011) (finding that most of the top 100 publicly traded companies "are moving toward voluntary disclosure of their corporate political spending, and nearly a third of them also place some limits on how much they spend on politics").

345. Ripken, supra note 66, at 174. See also DAN-COHEN, supra note 205, at 26 (criticizing as "great oversimplification[s]" past conceptualizations of the corporation). 
corporation. ${ }^{346}$ And that critically important point is all too often overlooked. When we properly vindicate the rights of corporations, we serve to effectuate the rights of fleshand-blood human beings who freely choose to associate with those corporationsincluding investors, managers, directors, employees, suppliers, and customers. By giving appropriate corporations a voice in the political process, we help give these individuals a voice too-permitting investors, consumers, business partners, and employees to combine their efforts via a common enterprise, and allowing them to be heard more loudly and effectively than if acting alone, dispersed, and in isolation. That is not only good for a democratic republic such as the United States, but absolutely essential.

346. Cf. DAN-COHEN, supra note 205, at $62-63$ (suggesting that corporate rights may be invoked from derivative rights of autonomy). 
